\title{
Simulating the effect of hypoxia on bay anchovy egg and larval mortality using coupled watershed, water quality, and individual-based predation models
}

\author{
Aaron T. Adamack ${ }^{1,2,6, *}$, Kenneth A. Rose ${ }^{1}$, Denise L. Breitburg ${ }^{3}$, Alex J. Nice ${ }^{4}$, \\ Wu-Seng Lung ${ }^{5}$ \\ ${ }^{1}$ Department of Oceanography and Coastal Sciences, Louisiana State University, Baton Rouge, Louisiana 70803, USA \\ ${ }^{2}$ Cooperative Institute for Limnology and Ecosystems Research, University of Michigan, Ann Arbor, \\ Michigan 48108, USA \\ ${ }^{3}$ Smithsonian Environmental Research Center, Edgewater, Maryland 21037, USA \\ ${ }^{4}$ URS Corporation, Morrisville, North Carolina 27560, USA \\ ${ }^{5}$ Department of Civil and Environmental Engineering, The University of Virginia, Thornton Hall, Charlottesville, \\ Virginia 22904-1000, USA \\ ${ }^{6}$ Present address: Institute for Applied Ecology, University of Canberra, Canberra, ACT 2601, Australia
}

\begin{abstract}
Greater nutrient loads since the 1950s have increased the extent and duration of hypoxic conditions in the Patuxent River and the Chesapeake Bay (Maryland, USA). We linked watershed, water quality, and individual-based predation models to predict how changes in local (Patuxent River watershed) and regional (bay-wide) nutrient loading rates would affect bay anchovy Anchoa mitchilli egg and larval mortality rates in the lower region of the Patuxent River. Nutrient loadings affected hypoxic volume and the degree of spatial overlap between anchovy and their predators. Mortality rates were simulated during June and July under combinations of a wet or dry year, reduced and increased nutrient loadings from the Patuxent River watershed, and increased and decreased nutrient loadings into the Patuxent River at the Chesapeake Bay boundary. Chesapeake Bay water quality at the downstream boundary had a much larger effect on egg and larval mortality rates than nutrient loading rates from the Patuxent River watershed, and these responses were consistent with the downstream boundary condition having a greater effect on hypoxia. Water column structure, year type (wet/dry), and location within the lower Patuxent River had smaller effects on egg and larval mortality. Due to indirect effects, the effect of the Chesapeake Bay boundary condition on larval mortality rates during June was opposite to that predicted for egg mortality rates. Our results illustrate that statements and justifications about the benefits of nutrient loading reductions on estuarine ecosystems should avoid oversimplification, be specific, and recognize that species responses to changes in environmental conditions can be complex and variable.
\end{abstract}

KEY WORDS: Patuxent River - Chesapeake Bay - Bay anchovy Anchoa mitchilli · Hypoxia · Early-life history $\cdot$ Mortality

\section{INTRODUCTION}

Coastal estuaries in many parts of the world have experienced increased rates of nutrient loading over the past century that has led to coastal eutro- phication and the formation of hypoxic and anoxic regions (Diaz \& Rosenberg 2008). Much of this increase in nutrient loading rates has been driven by changes in land use, increases in the use of fertilizer in agriculture, and increases in human 
population size. In response to coastal eutrophication, many jurisdictions have implemented, or are in the process of developing, plans to restore or improve estuarine water quality by reducing the nutrient loads being delivered to coastal estuaries. Examples include the North Sea (de Jong 2006), Chesapeake Bay (Boesch et al. 2001), and the Gulf of Mexico (Mississippi River/Gulf of Mexico Watershed Nutrient Task Force 2008). One difficulty that planners and resource managers face is determining the expected impact of changes in nutrient loading rates on higher trophic levels, such as fish. The water quality models that are often used to evaluate the potential effects of changes in nutrient loads are generally limited to predictions of water quality parameters (e.g. dissolved oxygen [DO], chlorophyll [chl] a), with limited representation of zooplankton and gelatinous predators, and no consideration of fish, while most fish management models ignore the effects of nutrients. Here we use a linked modeling approach to determine the effects of changes in Patuxent River water quality on the mortality of eggs and larvae of the bay anchovy Anchoa mitchilli.

Patuxent River water quality and the physical structure of the water column are both affected by changes in nutrient loading rates from the Patuxent River watershed, Chesapeake Bay water quality at the downstream boundary, and inter-annual variability in rainfall (Jordan et al. 2003, Lung \& Bai 2003, Weller et al. 2003, Fisher et al. 2006, Lung \& Nice 2007). Land use in the Patuxent River watershed has changed dramatically over the past $150 \mathrm{yr}$, from primarily agricultural ( $85 \%$ agriculture and $15 \%$ forested) in the $1850 \mathrm{~s}$ to a mix of forested $(51.6 \%)$, agriculture $(28.5 \%)$, residential $(15.5 \%)$, and urban $(4.3 \%)$ in 1994 (D'Elia et al. 2003). More recently, Boynton et al. (2008) compared land-use patterns in the watershed between 1992 and 2001 using data from the National Land Cover Database (Homer et al. 2007). They documented that developed land cover (urban, suburban, and other developed land) had increased from 11 to $17 \%$, agricultural land cover (row crops and pasture/hay) and forested land cover had remained about the same ( 32 to $34 \%$ and 42 to $40 \%$, respectively), while the other land cover categories (e.g. open water, wetlands) had decreased from 15 to $9 \%$. Changes in Patuxent River watershed land use and farming practices, and the accompanying increases in human population size, have resulted in a 2- to 5 -fold increase in nitrogen $(\mathrm{N})$ and phosphorus (P) inputs between 1970 and 2004, and may have caused a 4 - to 20 -fold increase in $\mathrm{N}$ and $\mathrm{P}$ over the last 350 yr (Fisher et al. 2006). Rapid population growth is expected to continue in the watershed for the near future, continuing these recent and longterm trends in land-use patterns (Bockstael \& Irwin 2003).

Chesapeake Bay water quality affects the water quality in the Patuxent River via tidal exchange of nutrients at the downstream boundary where the Patuxent River empties into the Chesapeake Bay (Boynton et al. 2008, Testa et al. 2008). Water quality in Chesapeake Bay has declined over the past century due to the effects of nutrient enrichment and overfishing (Kemp et al. 2005). While Chesapeake Bay has experienced hypoxia, at least occasionally, since the 1700s (Cronin \& Vann 2003), cultural eutrophication has caused the frequency, intensity, duration, and extent of hypoxia to increase over the past century (Hagy et al. 2004). Since 1983, there has been an ongoing effort to improve water quality in Chesapeake Bay and its tributaries (including the Patuxent River) through the reduction of nutrient and suspended-sediment loadings (Kemp et al. 2005, Powledge 2005).

Inter-annual variability in rainfall affects the magnitude of nutrient loadings and river flows in the Patuxent River (Jordan et al. 2003, Lung \& Nice 2007, Boynton et al. 2008). Variability in the magnitude of nutrient loadings affects the extent and intensity of hypoxia, while variability in river flows affects the degree of stratification. High water flow during wet years can amplify the effects of increased nutrient loadings on hypoxia by reducing the mixing between the oxygenated surface layer and the hypoxic bottom layer. Water quality modeling has shown that stratification and nutrient loads would increase in the Patuxent River during wet years (Jordan et al. 2003, Lung \& Bai 2003, Weller et al. 2003, Lung \& Nice 2007), leading to an earlier onset of hypoxia and a larger volume of hypoxic water compared to dry years (Hagy et al. 2004).

Water column DO concentrations can affect the mortality rates of fish eggs and larvae through both direct and indirect effects (Breitburg 1994, Breitburg et al. 1999, 2003). For example, bay anchovy eggs suffer direct mortality when DO concentrations fall below $3 \mathrm{mg} \mathrm{l}^{-1}$ for $\geq 12 \mathrm{~h}$ (Breitburg et al. 2003). Mortality rates may also be indirectly affected by changes in DO concentrations due to changes in the vertical distributions of fish larvae and their predators, resulting from differential avoidance of low DO (Breitburg et al. 1999, 2003). Changes in the vertical distribution of fish and their predators may either increase or decrease fish mor- 
tality rates, depending on whether the spatial overlap of the fish and their predators increases or decreases (Breitburg et al. 1999, 2003, Keister et al. 2000). Low DO may also increase larval mortality rates by slowing larval growth (Breitburg et al. 1999, 2003), extending the length of time that larvae are exposed to high predation rates (Houde 1987).

The potential effects of hypoxia and anoxia on fish have been clearly demonstrated in laboratory experiments and through local-scale field observations (e.g. Pihl et al. 1991, Breitburg 1992). However, it has been difficult to demonstrate that hypoxia has wide-scale population level effects on mobile fish species (Breitburg et al. 2009, Rose et al. 2009). The number of hypoxic zones worldwide has increased since the 1960s (Diaz \& Rosenberg 2008), making it increasingly more important to determine how hypoxia affects fish at levels beyond the individual.

In the present paper, we use a series of linked models (Fig. 1) to predict how changes in Patuxent River watershed land-use patterns affecting nutrient loading rates, Chesapeake Bay water quality, and interannual variation in rainfall would affect the survival of bay anchovy eggs and larvae during June and July in the lower Patuxent River (Fig. 2). We expected that scenarios that result in better water quality (e.g. increased bottom layer DO concentrations) would result in higher egg and larval survival, while scenarios that reduced water quality would result in lower egg and larval survival. The present study expands on the previous analysis by Breitburg et al. (1999) by using dynamic output from linked watershed, water quality, and predation models, and on that by Breitburg et al. (2003) by examining multiple months, year types (wet/dry), and changes in nutrient loads at the downstream (Chesapeake Bay) boundary, in addition to the changes in upstream nutrient loads that were examined by Breitburg et al. (2003).

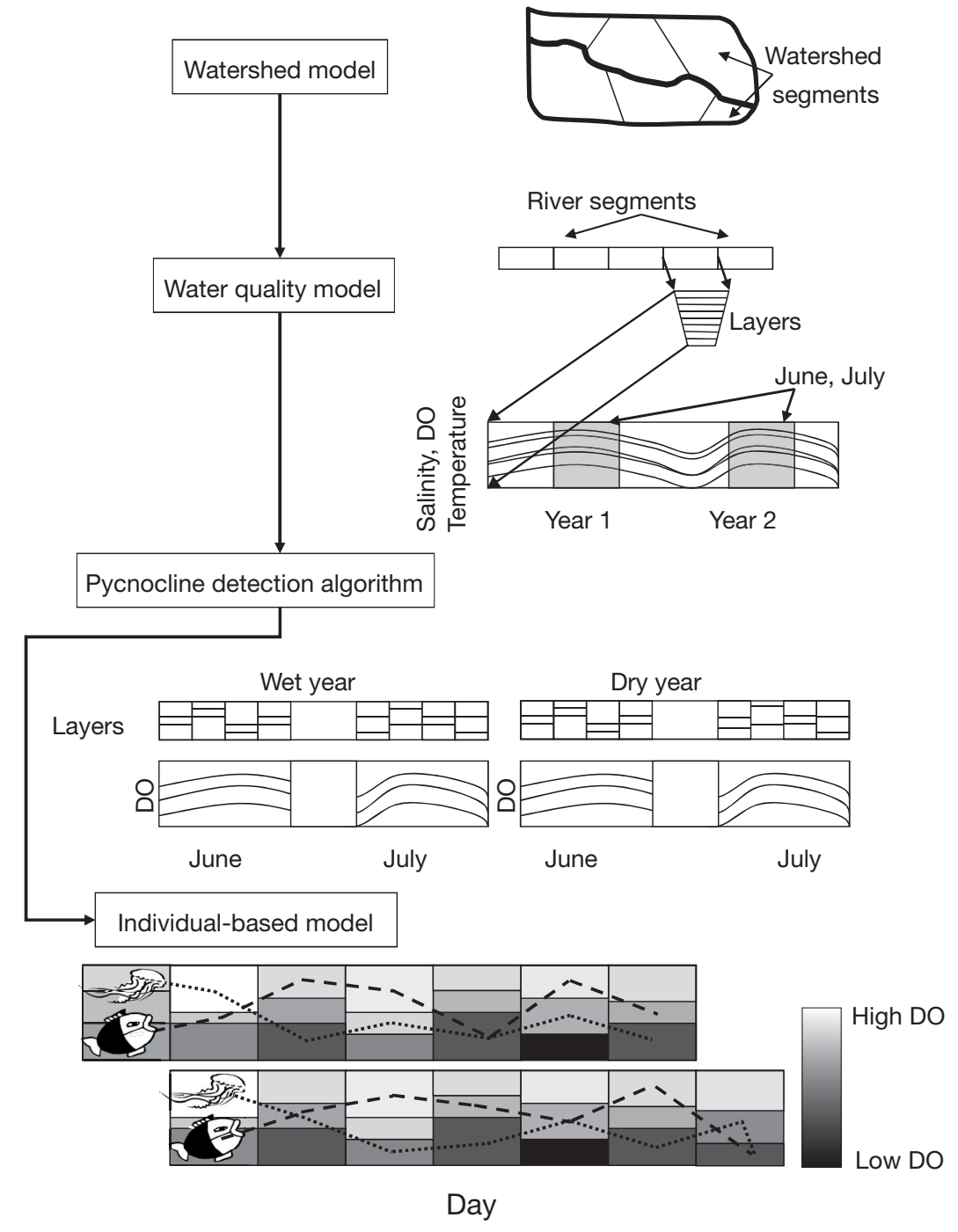

Fig. 1. The flow of information among the watershed model, water quality model, pycnocline detection algorithm, and the individual-based predation model. Arrows between models and algorithms show the direction of information flow. Weekly discharges of water and material concentrations from watershed segments of the watershed model are used as inputs to the river segments in the water quality model. Daily layer specific values of salinity, dissolved oxygen (DO), and water temperature during June and July are inputs to the pycnocline detection algorithm. Finally, the daily layer fractions and DO concentrations are used as inputs to the individual-based model. Fish and their predators then move daily in response to DO concentrations and water column structure

\section{METHODS}

We used 3 models (watershed, water quality and individual-based predation, with outputs from one model used as inputs to the next; Fig. 1) to simulate bay anchovy Anchoa mitchilli mortality across year types (wet/dry), under scenarios of altered Patuxent watershed nutrient loading rates and alternative assumptions about water quality at the Chesapeake Bay boundary. 


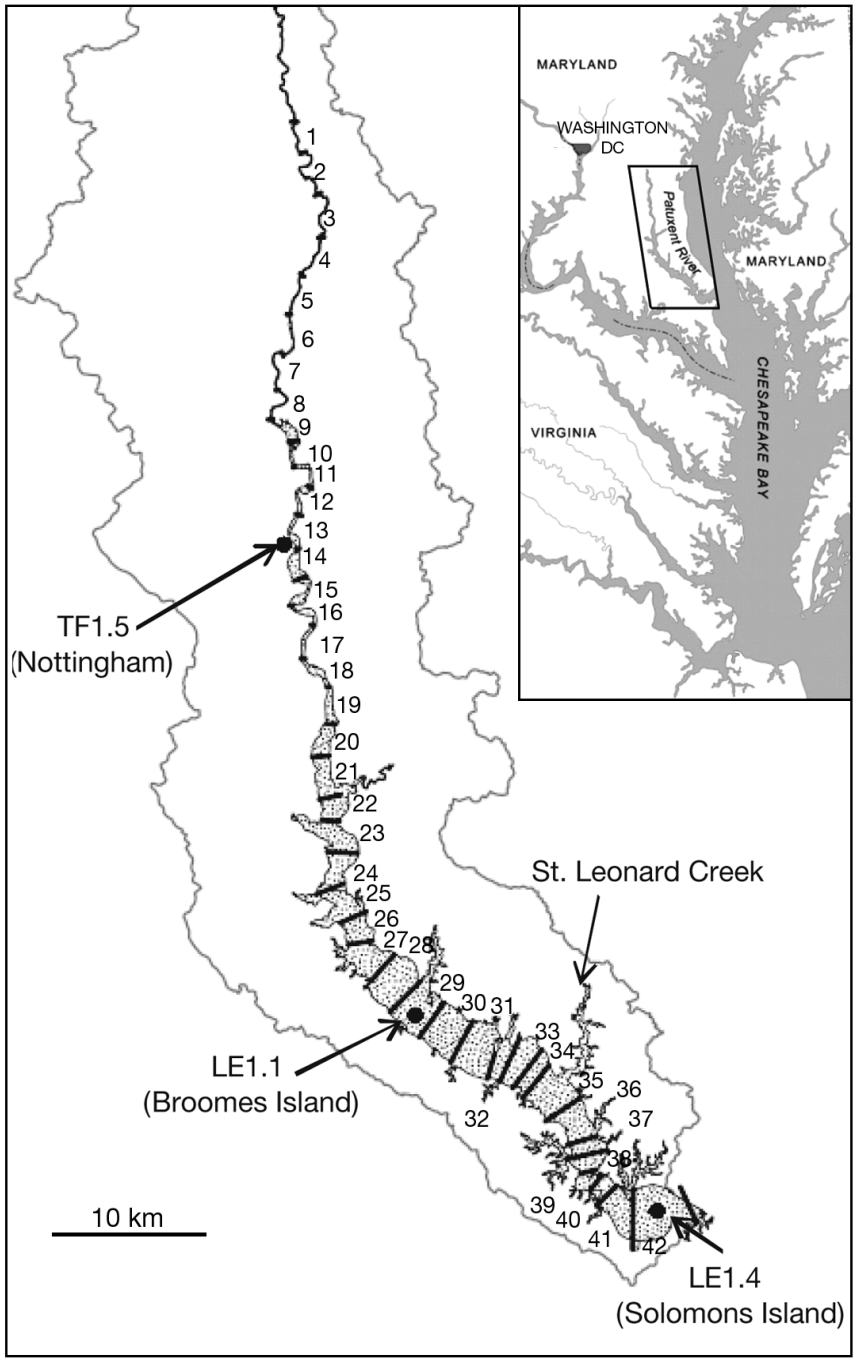

Fig. 2. The 42 river segments of the Patuxent River estuary. The segments were defined in Weller et al. (2003). $(\bullet)=$ monitoring stations for the water quality model

\section{Watershed model}

The Patuxent River watershed model is an empirical statistically based model that integrates nonpoint-source discharges, point-source discharges, and reservoir management to predict watershed discharges of water and material concentrations (including sediment, organic carbon, silicate, nitrogen, phosphorus, and ammonium) to the Patuxent River proper (Weller et al. 2003). Weekly data on nonpoint-source discharges and stream flow were collected for 23 watersheds within the Patuxent River drainage basin (17 watersheds) and the adjacent Rhode River basin (6 watersheds) from July 27, 1997 to August 4, 1999 were obtained from Jordan et al.
(2003). Linear statistical models were fit to the material discharge data and stream flow (Weller et al. 2003). Independent variables in each statistical model included week (104 wk), geological province (Piedmont or Coastal Plain), proportion of the watershed that was cropland, and proportion of the watershed that was developed land. Total $\mathrm{r}^{2}$ values for the models of material discharge ranged from 0.62 to 0.83 , with the exception of a low $\mathrm{r}^{2}$ for ammonium (total $r^{2}=0.18$ ). Total $r^{2}$ for non-point-source stream flow was 0.87 . Variables and interactions that were not statistically significant were then eliminated to create a set of reduced models.

The reduced statistical models were used to predict weekly non-point-source flows and material concentrations for the 23 watershed sections comprising the entire Patuxent River basin (Weller et al. 2003), which were then used as inputs to the spatial segments (see Fig. 2) of the water quality model. Pointsource flows, reservoir releases, and material concentrations were determined weekly and added to the predicted non-point-source values from the reduced statistical models to get weekly total flows and material concentrations from each watershed section for July 1997 to August 1999. Total flows and concentrations from the sections were then apportioned among the segments of the Patuxent River water quality model based upon estuary surface area.

\section{Water quality model}

The water quality model we used is the 2-dimensional (longitudinal-vertical) CE-QUAL-W2 model initially developed by the United States Army Corps of Engineers (Cole \& Wells 2000) and subsequently modified by Lung \& Bai (2003) and Lung \& Nice (2007) to model water quality in the Patuxent River. The water quality model divides the river into 163 longitudinal segments at the surface, each with a length of $613 \mathrm{~m}$. Each river segment is then divided into $1 \mathrm{~m}$ depth intervals for a total of 1993 spatial cells. The model uses finite-difference techniques to calculate water elevations and velocities by solving the laterally averaged free-water surface (continuity) equation and 2 laterally averaged momentum equations (Cole \& Wells 2000). The concentrations of 21 water quality constituents (e.g. salinity, temperature, DO, total nitrogen, and total phosphorus) are simulated in each of the cells using advective and dispersive transport from the water velocities and biochemical processes acting as internal sources and sinks. Major biochemical processes represented in the 
model include photosynthesis, sediment diagenesis, water column nutrient kinetics, and DO kinetics.

Boundary conditions for the water quality model include water flow and inputs into the river from the Patuxent River watershed and water quality inputs at the Chesapeake Bay boundary (Lung \& Nice 2007). Some watershed inputs were obtained from the output of the watershed model, while others not included in the watershed model (e.g. temperature, chl a) were estimated from Chesapeake Bay Program field data. Chesapeake Bay downstream boundary condition data for temperature, salinity, DO, and nutrients were set using data sampled at the Patuxent River water quality monitoring station LE1.4 (Fig. 2) and tidal water levels at Solomons Island in the lower Patuxent Estuary (NOAA 2003). Time varying climatic data includes air temperature, wind speed, wind direction, and cloud cover monitored at the Baltimore-Washington International Airport.

The water quality model was calibrated for July 1997 to August 1999 using longitudinal, temporal, and vertical comparisons of predicted temperature, salinity, chl $a$, DO, and nutrients to field data collected at water quality monitoring stations along the length of the Patuxent River. Longitudinal comparisons consisted of model and data values plotted at roughly 8 to $15 \mathrm{~km}$ increments from the river mouth every 1 to 3 mo during the 2 yr simulations. For temporal comparisons, approximately monthly model and data values were plotted together for the $2 \mathrm{yr}$ simulation period at 2 key sampling stations (Fig. 2): TF1.5 (also known as 'Nottingham'), which is tidal freshwater with historically high chl a levels, and LE1.1 (located near Broomes Island), which is saline and experiences hypoxia. Vertical profiles were snapshots every $2 \mathrm{wk}$ during the summer at the same 2 key sampling stations. Lung \& Nice (2007) present plots of these model-data comparisons; Nice (2006) also reported summary statistics of these comparisons. For the variables of particular interest here (salinity, temperature, DO), the median percent relative errors (median of $100 \times[D-M] / D$, where $D$ is a data value and $M$ is a model value) for longitudinal, temporal, and vertical comparisons were $<10 \%$ for salinity and temperature, and $\sim 12 \%$ for longitudinal and temporal comparisons and $22 \%$ for vertical comparisons of DO.

When referring to river segment numbers for the Patuxent River in the present paper, we use the same numbering system (shown in Fig. 2) as Breitburg et al. (2003) and Weller et al. (2003). This numbering system divides the Patuxent River into 42 river segments of varying length. The Patuxent River water quality model divides the river into 163 segments of fixed length, which results in there being multiple water quality model segments for each of our Patuxent River river segments. We chose a single water quality model segment to represent conditions in each river segment. The water quality model segments used to represent each of the river segments were selected based on their characteristics (e.g. location within the river segment, average water depth) and the similarity of their water quality dynamics to the dynamics in the equivalent segments of the earlier 42 segment water quality model (i.e. Lung \& Bai 2003).

We focus on model output from June and July for the mesohaline portion of the Patuxent River, concentrating on the section that extends from Broomes Island to below St. Leonard Creek (River Segments 30, 32, 34, and 36; Fig. 2). These river segments are located in an area with a history of summertime hypoxia (e.g. Breitburg et al. 2003, Lung \& Nice 2007 ) and where anchovies are abundant (e.g. Keister et al. 2000, Breitburg et al. 2003). Additionally, river segments represent steps along a depth continuum going from shallow (Segment 30, 18 m) to deep (Segment 36, 34 m). The water quality model segments used to represent conditions in the river segments were Segment 127 for River Segment 30, 135 for 32,137 for 34 , and 142 for 36 .

\section{Pycnocline detection}

The outputs of the water quality model were used as inputs to a pycnocline detection algorithm that was then used to define a 3-layer water column (surface, pycnocline, bottom) and subsequently the mean DO concentration in each water column layer for River Segments 30, 32, 34, and 36 for each day in June and July. The algorithm ${ }^{1}$ is described in more detail in the Appendix, including examples of its results compared to water quality model output. The algorithm first computed the density anomaly for each $1 \mathrm{~m}$ depth interval in a river segment from temperature and salinity values, and then used the vertical rate of change in the density anomaly to define the depths of the surface, pycnocline, and bottom layers. The mean DO concentration within a layer (surface, pycnocline, bottom) was determined as the average of the $1 \mathrm{~m}$ depth interval DO concentrations

\footnotetext{
1 Portions are described in EPA (2003) and further details were provided to the authors by T. R. Fisher of the Horn Point Laboratory, Center for Environmental Science, University of Maryland, 2020 Horn Point Rd, Cambridge, MD 21613, USA
} 
within a layer, weighted by the volume of water within each $1 \mathrm{~m}$ depth interval (determined from the input files of the water quality model). Layer thicknesses (sum of the depth intervals within a layer) were converted to fractions of the water column by dividing each layer thickness by the total depth of the water column. The time series of daily layer-specific mean DO values and the fraction of the water column in each of the 3 water column layers (surface, pycnocline, bottom) were used as inputs to the individualbased predation model.

\section{Individual-based predation model}

The individual-based model tracked the daily location, encounters with gelatinous predators, and mortality of individual fish eggs or fish larvae in the surface, pycnocline, and bottom layers defined by the pycnocline detection algorithm. The model simulated a single $2000 \mathrm{~m}^{3}$ water column that was divided into 3 layers (surface, pycnocline, bottom). Each day, the proportion of the water column (thickness) in each of the 3 layers and the DO concentrations in each layer were updated using the output from the pycnocline detection algorithm. Mortality of individual anchovy eggs and larvae were determined from their encounters with individual predators. Daily movement of eggs, larvae, and predators among the 3 layers depended on the DO concentration in the bottom layer. Eggs were followed for $1 \mathrm{~d}$, a time span approximately equal to the length of the egg stage (Chesney \& Houde 1989, Zastrow et al. 1991), while larvae were followed for $7 \mathrm{~d}$ corresponding to the critical period of very early larval feeding and high mortality.

Our focus on bay anchovy eggs and larvae is driven by the important role that they play in the Patuxent River ecosystem. Bay anchovy are among the most abundant species in the River and are a major component of the diets of predatory fish species (e.g. weakfish, striped bass, and bluefish; Baird \& Ulanowicz 1989). Additionally, anchovy play an important role in transferring energy from zooplankton to piscivorous fish, consuming from 15 to $18 \%$ of the zooplankton production during the summer in Chesapeake Bay and contributing from 60 to $90 \%$ of the energy consumed by carnivorous fish (Baird \& Ulanowicz 1989).

The individual-based model was modified from Breitburg et al. (1999) to allow the use of temporally varying DO concentrations and layer thicknesses, and the DO variable was changed from a discrete variable to a continuous variable (modifications described in Breitburg et al. 2003). These changes allowed us to use daily output from the water quality model as an input to the individual-based model. The earlier model (Breitburg et al. 2003) was further modified for the current study to allow larval lengths to modify predator capture success (Cowan \& Houde 1992). This modification was made in order to make changes in predator capture success more realistic as larvae outgrew their predators.

Each simulation started with 200000 eggs or 100000 larvae, with egg lengths $\left(L_{\mathrm{E}}\right)$ fixed at $1 \mathrm{~mm}$ and initial larval lengths $\left(L_{\mathrm{L}}\right)$ generated from a normal distribution (Table 1). The numbers of sea nettle Chrysaora quinquecirrha and ctenophore Mnemiopsis leidyi predators in the water column were specified (detailed below), and their sizes (bell diameter for medusae $\left[L_{\mathrm{SN}}\right]$; body length for ctenophores $\left[L_{\mathrm{C}}\right]$ ) were generated from normal probability distributions (Table 1). Minimum and maximum sizes were specified to prevent unrealistic sizes from being generated from the normal distributions. If the size generated was outside of the range between the minimum and maximum sizes, then a new random deviate was generated.

On each day, each individual anchovy egg (followed for $1 \mathrm{~d}$ ) or larva (folowed for $7 \mathrm{~d}$ ) was evaluated for growth (larva only), whether it had been eaten by any of the predators in that layer, and its movement among the 3 vertical layers in the water column. Egg and predator lengths remained constant throughout the simulation. Length of each individual larva was increased each day (growth) based on an assigned growth rate $\left(0.23 \mathrm{~mm} \mathrm{~d}^{-1}\right.$; Breitburg et al. 1999). Larval growth rates were not affected by DO when DO was $\geq 4 \mathrm{mg} \mathrm{l}^{-1}$, but decreased linearly to $60 \%$ of the assumed rate at $3 \mathrm{mg} \mathrm{l}^{-1}, 20 \%$ at $2 \mathrm{mg} \mathrm{l}^{-1}$, and to $0 \%$ at DO concentrations $\leq 1 \mathrm{mg} \mathrm{l}^{-1}$ (Breitburg et al. 1999). The probability of eggs dying due to direct exposure to low DO concentration was based upon the results of Chesney \& Houde (1989). The proportion dying per day was 1.0 at $\mathrm{DO} \leq 1 \mathrm{mg} \mathrm{l}^{-1}$, decreased linearly to 0.5 at $2.8 \mathrm{mg} \mathrm{l}^{-1}$, and then decreased linearly to 0 for DO $\geq 3 \mathrm{mg} \mathrm{l}^{-1}$. We assumed that larval anchovy were able to avoid lethal hypoxic conditions and therefore did not suffer mortality due to low DO concentrations. Predation by non-gelatinous predators and other sources of natural mortality besides ctenophores and sea nettles were not included in simulations.

Predation mortality was evaluated each day for each surviving individual egg or larva. The mean number of encounters of each prey (eggs or larvae) with each individual predator was computed using a modified Gerritsen \& Strickler (1977) formulation (Bailey \& Batty 1983). Individual predators and prey 
Table 1. Initial values used for the individual-based predation model simulations. Predator sizes and densities were based directly on field measurements by Kolesar (2006). Different portions of the ctenophore Chrysaora quinquecirrha populations were used for the bay anchovy Anchoa mitchilli egg and larva (prey) simulations. The smallest ctenophores captured as a part of field sampling were $10 \mathrm{~mm}$ in length (i.e. able to eat anchovy eggs), but ctenophores $<25 \mathrm{~mm}$ are too small to capture larval anchovy. For anchovy egg simulations, the sizes and densities of ctenophores were based on all ctenophores captured during field sampling (i.e. those $\geq 10 \mathrm{~mm}$ long). For anchovy larva simulations, ctenophore sizes and densities were based on all ctenophores > $25 \mathrm{~mm}$ that were captured during sampling. Sea nettles Mnemiopsis leidyi were absent (-) during June and were thus not included in June simulations. Values are means $( \pm \mathrm{SD})$ where applicable. NA: data not applicable to the simulation

\begin{tabular}{|c|c|c|c|c|c|c|c|c|c|c|c|}
\hline \multirow{3}{*}{ Month } & \multicolumn{3}{|c|}{ Initial prey } & \multirow{2}{*}{\multicolumn{5}{|c|}{ Ctenophore }} & \multirow{3}{*}{$\begin{array}{l}\text { Density } \\
\text { (ind. } \mathrm{m}^{-3} \text { ) }\end{array}$} & \multirow{3}{*}{$\begin{array}{l}\text { Sea nettle } \\
\text { Bell } \\
\text { diam. } \\
(\mathrm{mm})\end{array}$} & \multirow{3}{*}{$\begin{array}{c}\text { Min., } \\
\text { max. } \\
\text { bell } \\
\text { diam. } \\
(\mathrm{mm})\end{array}$} \\
\hline & \multirow{2}{*}{$\begin{array}{l}\text { Density } \\
\text { (ind. } \mathrm{m}^{-3} \text { ) }\end{array}$} & \multirow{2}{*}{$\begin{array}{l}\text { Length } \\
(\mathrm{mm})\end{array}$} & \multirow{2}{*}{$\begin{array}{c}\text { Min., } \\
\text { max. } \\
\text { start } \\
\text { length } \\
(\mathrm{mm})\end{array}$} & Density (ind. $\mathrm{m}^{-3}$ ) & & & & & & & \\
\hline & & & & $\begin{array}{l}\geq 10 \mathrm{~mm} \\
\text { length }\end{array}$ & $\begin{array}{l}\geq 25 \mathrm{~mm} \\
\text { length }\end{array}$ & $\geq 10 \mathrm{~mm}$ & $\geq 25 \mathrm{~mm}$ & $\begin{array}{l}\text { Min., } \\
\text { max. }\end{array}$ & & & \\
\hline \multicolumn{12}{|c|}{ Egg predation } \\
\hline Jun & 100 & $1.0 \pm 0.0$ & $1.0,1.0$ & 3.7 & NA & $21 \pm 12$ & NA & 10,90 & - & - & - \\
\hline Jul & 100 & $1.0 \pm 0.0$ & $1.0,1.0$ & 2.5 & NA & $58 \pm 19$ & NA & 10,106 & 0.05 & $69 \pm 37$ & 25,170 \\
\hline \multicolumn{12}{|c|}{ Larval predation } \\
\hline Jun & 50 & $2.8 \pm 0.5$ & $2.3,3.2$ & NA & 1.0 & NA & $36 \pm 13$ & 25,90 & - & - & - \\
\hline Jul & 50 & $2.8 \pm 0.5$ & $2.3,3.2$ & NA & 2.5 & NA & $59 \pm 20$ & 25,106 & 0.05 & $69 \pm 37$ & 25,170 \\
\hline
\end{tabular}

only interacted with each other when they were in the same layer as one another. The mean number of encounters in a day between a prey and each predator in the same layer $(\bar{E})$ was computed as:

$$
\begin{gathered}
\bar{E}=\pi\left(R_{\mathrm{L}}+R_{\mathrm{P}}\right)^{2} \times C \times\left(10^{-9} \times V^{-1}\right) \\
C= \begin{cases}\frac{D_{\mathrm{L}}^{2}+3 D_{\mathrm{P}}^{2}}{3 D_{\mathrm{P}}} & \text { if } D_{\mathrm{P}}>D_{\mathrm{L}} \\
\frac{3 D_{\mathrm{L}}^{2}+D_{\mathrm{P}}^{2}}{3 D_{\mathrm{L}}} & \text { if } D_{\mathrm{P}}<D_{\mathrm{L}}\end{cases}
\end{gathered}
$$

where $C$ is the foraging rate $\left(\mathrm{mm} \mathrm{d}^{-1}\right), R_{\mathrm{P}}$ is the encounter radius (the range within which a predator can detect or entangle their prey and prey can detect their predator) of the predator $(\mathrm{mm}), R_{\mathrm{L}}$ is the encounter radius of the prey $(\mathrm{mm}), D_{\mathrm{P}}$ is the distance swum in a day by the predator $(\mathrm{mm}), D_{\mathrm{L}}$ is the distance swum in a day by the prey $(\mathrm{mm})$, and $V$ is the modeled volume of the layer $\left(\mathrm{m}^{3}\right)$. Swimming speeds and encounter radii for prey and predators were adapted from previous applications of the individualbased predation model (Cowan \& Houde 1992; shown here in Table 2). Eggs were assumed to have a zero swimming speed and an encounter radius of zero. The actual number of encounters was generated from a Poisson distribution with $\bar{E}$ as the mean. Whether an encounter led to a successful capture was then determined from capture success. Predator capture success was assumed to be 0.8 for eggs as prey, regardless of DO level based on laboratory observations (see Table 1 in Rose et al. 1999). Ctenophore capture success of larvae increased with ctenophore length and decreased with increasing larval length (Table 2); sea nettle capture probability of larvae increased to a maximum with increasing sea nettle length and decreased slightly with increasing larval length (Table 2). Sea nettle capture success of larvae was increased at low levels of DO, while ctenophore capture success was unaffected by DO (Fig. 3). Finally, the realized number eaten by a predator was generated from a binomial distribution, where the actual number encountered was the number of trials, and capture success was the probability of a success. An egg or larva was considered eaten and removed from the simulation if any of the predators in the layer had at least 1 successful capture of that egg or larva.

Movement was simulated by randomly reassigning all prey and predator individuals to a new layer each day based upon specified proportional densities by layer and the DO concentration in the bottom layer (Fig. 4). Proportional densities by layer were based on results of field sampling in the Patuxent River (Breitburg et al. 1999, 2003, Keister et al. 2000). The probability that a prey or predator would move to a layer (surface, pycnocline, or bottom) was computed as the proportional density expected in that layer (from bottom DO) times the fraction of the water column volume in that layer, divided by the sum of the proportional densities times fractional volumes of all 3 layers. A cumulative distribution of the 3 probabilities was then formed, and a random number was generated and used to determine the layer that the individual moved to for the next day. 
Table 2. Anchoa mitchilli, Mnemiopsis leidyi and Chrysaora quinquecirrha. Encounter radii and distances swum in a day for larval bay anchovy, ctenophores, and sea nettles (from Cowan \& Houde 1992), and capture probability relationships of ctenophores (C) and sea nettles (SN) eating bay anchovy larvae (L) modified from Cowan \& Houde (1992). L: length; NA: not applicable

\begin{tabular}{|lccc|}
\hline Parameter & Larval bay anchovy & Ctenophore & Sea nettle \\
\hline Encounter radius $(\mathrm{mm})$ & $\frac{2 \times L_{\mathrm{L}}}{\pi^{2}}$ & $0.33 \times L_{\mathrm{C}}$ & $0.5 \times L_{\mathrm{SN}}$ \\
Distance swum $\left(\mathrm{mm} \mathrm{d}^{-1}\right)$ & $1.5 L_{\mathrm{L}} \times 46800$ & $0.025 \times L_{\mathrm{C}} \times 86400$ & $1.2+0.04 \times L_{\mathrm{SN}} \times 86400$ \\
Realized capture probability & $\mathrm{NA}$ & $0.813-4.416 \frac{L_{\mathrm{L}}}{L_{\mathrm{C}}}$ & $0.505+4.653 \frac{L_{\mathrm{L}}}{L_{\mathrm{SN}}}-66.215\left(\frac{L_{\mathrm{L}}}{L_{\mathrm{SN}}}\right)^{2}+155.377\left(\frac{L_{\mathrm{L}}}{L_{\mathrm{SN}}}\right)^{3}$ \\
\hline
\end{tabular}

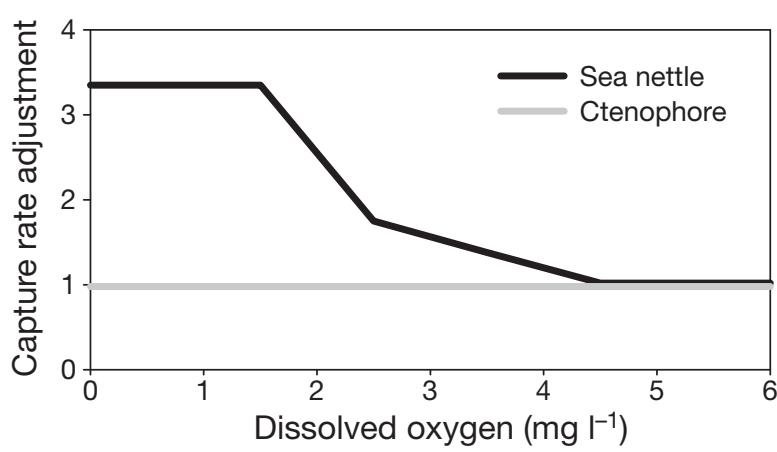

Fig. 3. Adjustment (based on dissolved oxygen levels) of the capture success rate of sea nettles Chrysaora quinquecirrha and ctenophores Mnemiopsis leidyi capturing eggs and larvae of bay anchovy Anchoa mitchilli (from Breitburg et al. 1999, 2003)

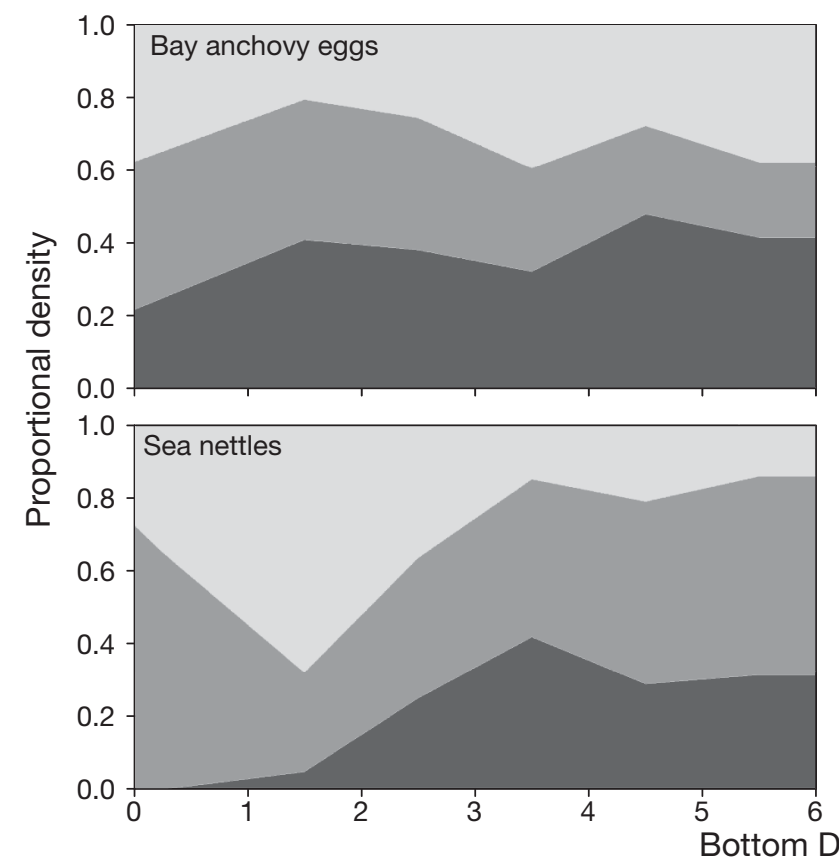

\section{Simulations}

The linked models were used to predict daily egg mortality and $7 \mathrm{~d}$ larval mortality rates for River Segments 30, 32, 34, and 36 for each day in June and in July for 18 combinations of 2 year types (wet and dry), 3 Patuxent watershed land-use scenarios, and 3 Chesapeake Bay boundary conditions (described below, this subsection). The watershed and water quality model simulations covered 2 yr (August 1997 through July 1999; Lung \& Nice 2007). Daily values of temperature, salinity, and DO by $1 \mathrm{~m}$ depth increments for June and for July during each of the years were extracted for River Segments 30, 32, 34, and 36 from the water quality model simulations. The pyc-


Fig. 4. Anchoa mitchilli, Chrysaora quinquecirrha and Mnemiopsis leidyi. Proportional densities of bay anchovy eggs and larvae, sea nettles, and ctenophores as a function of bottom dissolved oxygen (DO) concentration. Proportional densities are calculated as the proportion of individuals that would be in surface, pycnocline, and bottom water layers if all layers of the water column were equal in volume. Data points were linearly interpolated to allow vertical distributions to be adjusted for continuous bottom DO concentrations 
nocline detection algorithm was applied to these daily values by depth increment to obtain the daily thicknesses of the surface, pycnocline, and bottom layers and daily mean DO concentration within a layer. These values were then used as input for the individual-based predation model, which predicted 1 $\mathrm{d}$ egg mortality rates and $7 \mathrm{~d}$ larval mortality rates for cohorts (initially 200000 eggs or 100000 larvae) initiated on each day. Simulations for eggs and larvae were run separately and did not affect one another.

We considered the first year of the simulation (August 1997 to July 1998) as representing a wet year and the second year (August 1998 to July 1999) as representing a dry year. Annual precipitation was $122 \mathrm{~cm}$ during the first year and $71 \mathrm{~cm}$ during the second year (Jordan et al. 2003), compared to a mean $( \pm \mathrm{SD})$ of $108 \pm 21.8 \mathrm{~cm}$ for a $160 \mathrm{yr}$ precipitation record (Correll et al. 1999).

The 3 Patuxent land-use scenarios were current conditions (current), increased nutrient loadings (increased) caused by doubling the proportion of developed land area and point-source discharges, and reduced nutrient loadings (reduced) caused by halving cropland, developed land, and point-source discharges. The increased nutrient loading scenario resulted in the average annual total $\mathrm{N}$ load to the Patuxent River increasing by $155 \%$ and the average annual total P load increasing by $146 \%$ over current conditions, while the reduced nutrient loading scenario resulted in a $53 \%$ reduction in the annual total $\mathrm{N}$ load and a $57 \%$ reduction in the annual total $\mathrm{P}$ load (Weller et al. 2003).

The 3 downstream boundary condition scenarios were baseline nutrients and carbonaceous biochemical oxygen demand (1997 to 1999 conditions), and baseline nutrient concentrations and carbonaceous biochemical oxygen demand halved $(0.5 \times)$ and increased by $50 \%(1.5 \times)$ (Nice 2006). We did not vary the influx rates of water, temperature, or salinity from their baseline values as part of the altered boundary conditions, as these values would not be affected by changes in nutrient loadings. DO concentrations at the downstream boundary were not varied, as these water quality model simulations were designed to examine the sensitivity of DO concentrations to changes in nutrient loadings. We note that changes in watershed nutrient loadings from the land-use scenarios did not affect conditions at the downstream boundary, as the scenarios were implemented independently of one another. Conditions (nutrient loads and carbonaceous biochemical oxygen demand) for the downstream boundary were determined by multiplying the observed conditions at Patuxent
River water quality monitoring station LE1.4 by a constant (e.g. $0.5 \times, 1.0 \times$, or $1.5 \times$ ) corresponding to the downstream boundary condition scenario.

After several initial simulations, we made 1 additional simplification in the linked model analysis by determining a single set of daily layer thicknesses for the wet year and a single set for the dry year. This simplification was done in order to standardize the determination of water column structure on days when layers were only weakly identified by the pycnocline detection algorithm. The vertical structure of the water column was insensitive to land-use scenarios and Chesapeake Bay boundary conditions. We applied the pycnocline detection algorithm to each of the 9 simulations ( 3 land-use and 3 boundary conditions) for the wet year and to the 9 simulations for the dry year. We then determined the thickness of the 3 layers for each day in June and in July by examining plots and, when needed, slightly smoothing over the 9 different estimates for each day to obtain a single set of thicknesses for the wet year and a single set for the dry year.

The model outputs we analyzed were the egg and larval mortality rates generated by the individualbased predation model. All reported mortality rates, unless otherwise specified, are based on the entire modeled population and include all sources of mortality included in model simulations. Egg simulations in each month and river segment were $1 \mathrm{~d}$ simulations using the water quality conditions on each day. Thus, there were 30 egg mortality rates in each river segment for June and 31 values for each river segment for July. The larval simulations were $7 \mathrm{~d}$ in duration, beginning on each day of the month, resulting in 30 values of $7 \mathrm{~d}$ mortality rates for June and 25 values for July for each river segment. For example, the larval mortality rate for Day 4 was computed over Days 4 to 10, for Day 5 over Days 5 to 11, etc. July had only 25 predictions (not 31 ) because the last $7 \mathrm{~d}$ of July were not simulated, as the values needed from the water quality model for the first week of August were not available.

For all simulations, the model results of bottom layer DO, and egg and larval mortality rates were summarized by month and river segment by combining the daily values for each month (30 values for June; 31 egg values and 25 larval values for July) and then displaying them as box plots. Daily values of the thickness of the layers in each simulation were averaged to obtain single values by month and river segment. We also present daily values of some variables for specific river segments and scenarios to illustrate model results and to help 
interpret the monthly summaries. We show the daily DO, water layer thicknesses, and predicted mortality rates as time series for June and July in Segment 34 in the wet year. We also show the daily percentage of individuals in each layer for larvae and ctenophores for a $7 \mathrm{~d}$ period during June for the wet year under current Patuxent watershed nutrient loading rates and each of the 3 Chesapeake Bay boundary conditions.

All results were from single simulations of the individual-based predation model. The model is stochastic, and random numbers are generated that affect the individual initial sizes of predators, the daily redistribution of prey and predators among the 3 layers, and the outcome of encounters between individual prey and predators. Replicate simulations that differed in their random number sequences generated similar predicted egg mortality and larval mortality rates. Differences in egg mortality rates among replicate simulations were $<3 \% \mathrm{~d}^{-1}$ and differences among 7 d larval mortality rates were $<5 \%$ during June and $<0.6 \%$ during July.

\section{RESULTS}

\section{Water column structure and DO concentrations}

The estimated water column structure varied among days (e.g. bars in Fig. 5A), and monthly summaries showed consistent differences between June and July, across river segments, and between the wet and the dry year (Fig. 6). Pycnocline thickness was higher and bottom layer thickness lower in the wet year as compared to the dry year (left versus right panels in Fig. 6). Bottom layer thickness increased with distance downstream (River Segments 30 to 36 in Fig. 6). The difference between June and July was smaller in magnitude than the effects of wet versus dry year and river segment, and depended on whether it was the wet or dry year. For each river segment, the wet year resulted in a thicker pycnocline and thinner bottom layer in July compared to June, while the dry year resulted in a thinner pycnocline and thicker surface layer in July compared to June. Using River Segment 34 as an example (Fig. 6), in the wet year, the pycnocline layer increased from $42 \%$ of the water column in June to $53 \%$ in July, while the bottom layer decreased from 22 to $15 \%$. In the dry year, the pycnocline decreased from $25 \%$ of the water column in June to $19 \%$ in July, while the surface layer increased from 40 to $46 \%$.
At times, bottom DO concentrations also showed wide daily fluctuations (lines in Fig. 5A), with the Chesapeake Bay boundary conditions having the largest effect (Fig. 7). Bottom layer DO concentrations decreased with increasing boundary condition nutrient loadings. During both the wet and the dry year, bottom layer DO concentrations for the $0.5 \times$ Chesapeake boundary condition were $\sim 1 \mathrm{mg} \mathrm{l}^{-1}$ higher than bottom layer DO concentrations for the baseline boundary condition scenario, which, in turn, were $\sim 0.5 \mathrm{mg} \mathrm{l}^{-1}$ higher than the $1.5 \times$ boundary condition. Pycnocline layer DO concentrations (not shown) were usually about $2 \mathrm{mg} \mathrm{l}^{-1}$ higher than bottom layer DO concentrations, and roughly paralleled the patterns in bottom layer DO. When bottom layer DO concentrations were $\leq 1 \mathrm{mg} \mathrm{l}^{-1}$, DO concentrations in the pycnocline layer frequently dipped below $3 \mathrm{mg} \mathrm{l}^{-1}$, the level at which egg mortality due to hypoxia occurred. Surface layer DO concentrations (not shown) were consistently $>5 \mathrm{mg} \mathrm{l}^{-1}$.

Bottom layer DO concentrations also showed a large difference between the wet and the dry year, and small differences between months and across river segments. Median bottom DO concentrations were lower in the wet year than in the dry year. For the same land-use scenario and boundary condition, median concentrations were 0.75 to $1.5 \mathrm{mg} \mathrm{l}^{-1}$ lower for the wet versus the dry year in June and 0.8 to $1.9 \mathrm{mg} \mathrm{l}^{-1}$ lower in July (Fig. 7). Daily DO concentrations in the bottom layer in the wet year tended to be lower and less variable during July than June (Figs. 5A [lines] \& 7) with a $0.55 \mathrm{mg}^{-1}$ average drop in median bottom layer DO between June and July for scenarios with common land-use and boundary conditions. Bottomlayer DO increased moving downstream from Segment 30 to 36 (Fig. 7).

\section{Egg mortality rates}

Anchoa mitchilli egg mortality rates showed daily variability (reflecting bottom DO; Fig. 5C), and were most affected by the Chesapeake Bay boundary condition (Fig. 8). Median mortality rates ranged from $\sim 18 \% \mathrm{~d}^{-1}$ in June under the $0.5 \times$ boundary condition to $\sim 40 \% \mathrm{~d}^{-1}$ under the $1.5 \times$ boundary condition, and from $\sim 46 \% \mathrm{~d}^{-1}$ under the $0.5 \times$ to $\sim 61 \% \mathrm{~d}^{-1}$ under the $1.5 \times$ boundary condition in July (Fig. 5C). Most of the mortality of eggs in the bottom layer was due to hypoxia rather than predation (Fig. 5B). 



Fig. 5. Anchoa mitchilli. (A) Daily water column structure and bottom layer dissolved oxygen (DO) concentration, (B) percentage of all eggs present that are in the bottom layer and their fate, (C) $1 \mathrm{~d}$ egg mortality rates (whole water column), and (D) 7 d larval bay anchovy mortality rates (whole water column) for the 3 land-use and 3 Chesapeake Bay boundary condition scenarios for River Segment 34 during June and July of the wet year. In (A), bars show the fraction of the water column in each layer (light gray = surface, medium grey = pycnocline, dark grey $=$ bottom), plot lines show daily bottom layer DO concentrations, and horizontal lines indicate DO concentrations of 3, 2.8 and $1.0 \mathrm{mg} \mathrm{l}^{-1}$, which correspond to 0,50 and $100 \%$ egg mortality due to low DO concentrations. Water column structure in (A) is constant across Patuxent River watershed land-use and Chesapeake Bay boundary condition scenarios. Panel B only shows results for 1 simulation (current land-use and baseline boundary condition)

Higher egg mortality rates in July compared to June were due to lower DO (Fig. 7), increased ctenophore size, and the addition of predation by sea nettles (Table 1). Bottom DO concentrations were consistently about $0.5 \mathrm{mg} \mathrm{l}^{-1}$ lower in July than in June, which was often the difference between the pycnocline being above or below the $3 \mathrm{mg} \mathrm{l}^{-1}$ thresh- old for direct mortality. While ctenophore density decreased between June and July (3.7 to $2.5 \mathrm{~m}^{-3}$ ), their mean lengths more than doubled (from $21 \mathrm{~mm}$ in June to $58 \mathrm{~mm}$ in July), and the mean volume of water searched per individual (determined by multiplying distance swum in a day by their search area) increased 21 -fold. Sea nettles were absent in June, but were present in July (Table 1).

The effects of year type (wet/dry) and river segment on egg mortality rates were inconsistent in direction and small in magnitude relative to the effect of month (Fig. 8). During June, median egg mortality rates for a river segment were higher for the wet year than the dry year in 29 out of the 36 simulation combinations. For example, in River Segment 36 for the baseline boundary condition, the median mortality for eggs was $\sim 25 \% \mathrm{~d}^{-1}$ for the wet year and $\sim 18 \% \mathrm{~d}^{-1}$ for the dry year. During July, median egg mortality rates for a river segment were sometimes (21 out of 36 simulations) higher in the dry year and sometimes (15 out of 36 simulations) higher in the wet year, depending upon the river segment and Chesapeake Bay boundary condition scenario. July median egg mortality rates were lower in the dry year than the wet year in all river segments for the $0.5 \times$ baseline boundary condition scenario. However, under the baseline boundary condition the effects of year type (wet vs. dry) varied across segments. Mortality rates were about $9 \%$ lower in the dry year versus the wet year for River Segment 30, but mortality rates were higher in the dry year by $6 \%$ for Segment 32, by $3.4 \%$ for Segment 34, and by $1.5 \%$ for Segment 36. July mortality rates were also not consistently lower in the dry year under the $1.5 \times$ boundary condition. July mortality rates during the dry year were lower than in the wet year by $12.3 \%$ in Segment 30 and by $3.4 \%$ in Segment 32, but higher in Segments 34 and 36 (by 3.1 and $3.9 \%$, respectively). 


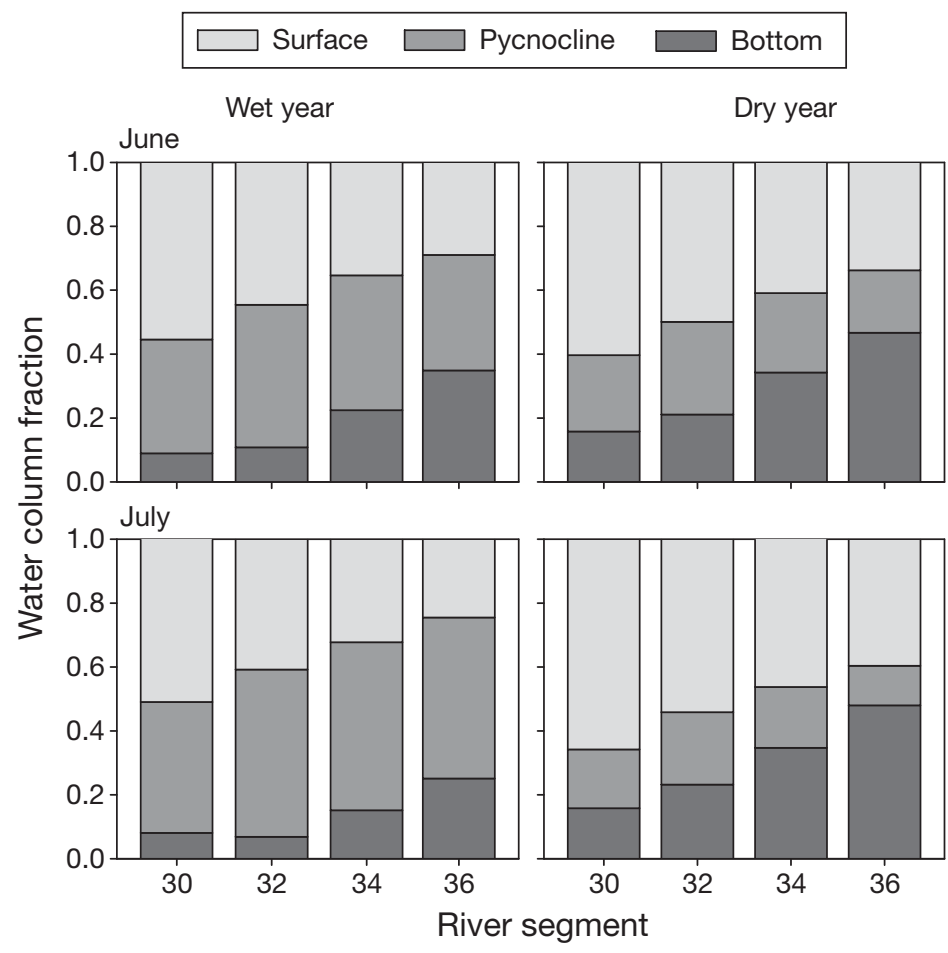

Fig. 6. Water column fractions by layer averaged over each month for a wet and a dry year during June and July

\section{Larval mortality rates}

Daily and monthly summarized larval mortality rates varied little across scenarios compared to egg mortality rates (Fig. $5 \mathrm{D}$ versus $\mathrm{C}_{i}$ Fig. 9 versus Fig. 10, note the scale of the $y$ axis). This was especially true in July, when larval mortality rates were uniformly high and varied little among river segments and between the wet and the dry years. Reduced variability in predicted larval mortality rates was partly due to rates being computed for overlapping $7 \mathrm{~d}$ periods, and thereby smoothing over day-to-day variability in DO concentrations.

Focusing on the June rates, larval mortality rates, like egg rates, were most affected by the Chesapeake Bay boundary conditions, but unlike egg mortality rates, larval mortality rates decreased with increasing boundary condition nutrient loads (Fig. 9). Larval mortality rates were highest for the $0.5 \times$ boundary condition, while the rates for baseline and $1.5 \times$ boundary conditions were lower and sometimes overlapped with each other.

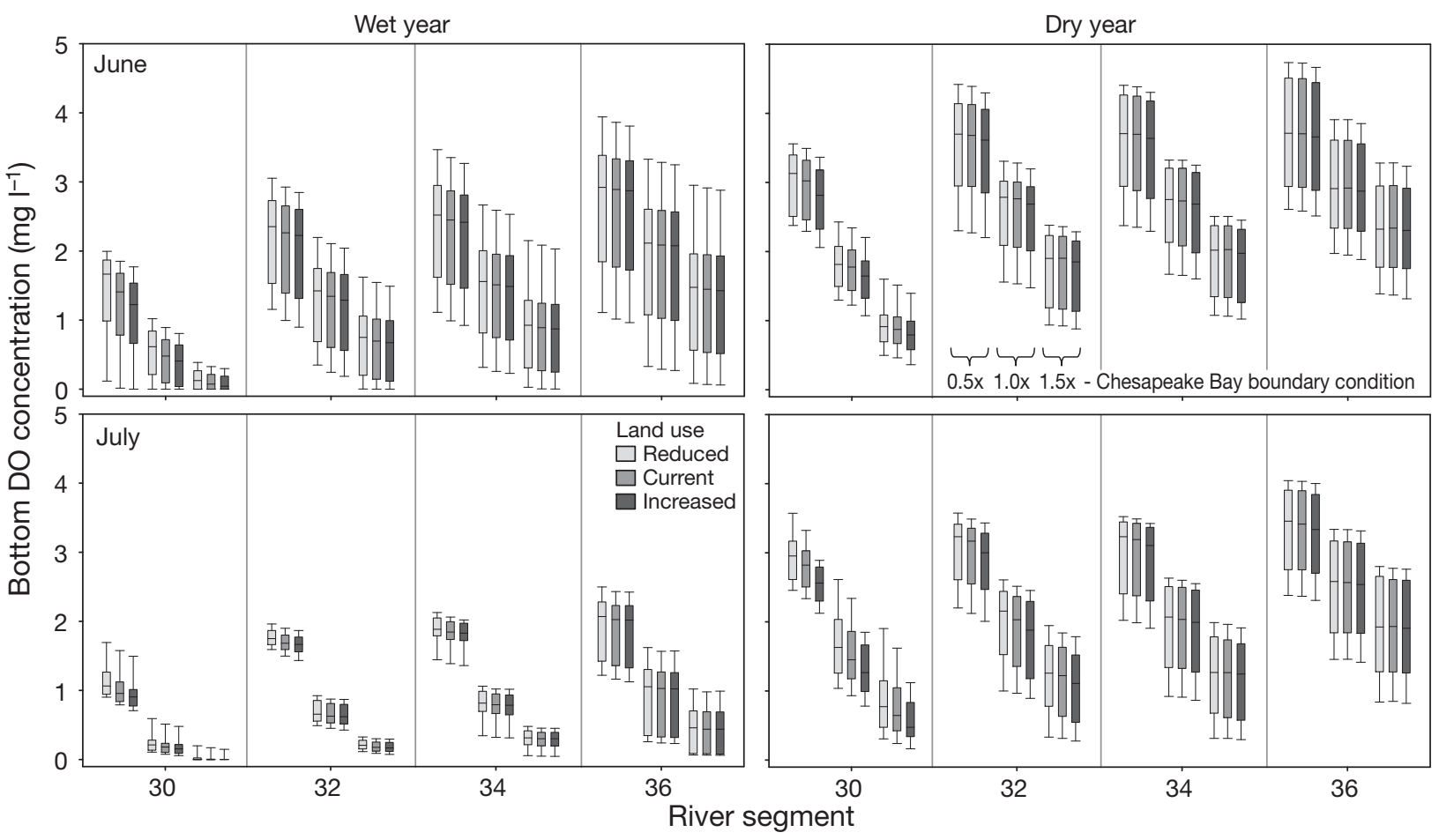

Fig. 7. Boxplots showing monthly bottom layer dissolved oxygen (DO) concentrations by river segment for a wet and a dry year during June and July for each Patuxent River watershed land-use scenario and Chesapeake Bay boundary condition scenario. For each river segment, 3 triplets are shown. Each triplet shows the watershed land-use scenarios (reduced, current, and increased nutrient loadings indicated by differently shaded bars) under different Chesapeake Bay boundary condition scenarios (first triplet $=0.5 \times$ baseline boundary condition scenario, second triplet $=1.0 \times$ baseline, third triplet $=1.5 \times$ baseline) . As an example, triplets are labeled for June of the dry year in Segment 32. Whiskers show the 10th and 90th percentiles of the distribution, the box shows the 25th and 75th percentiles, and the solid line in the box shows the median 


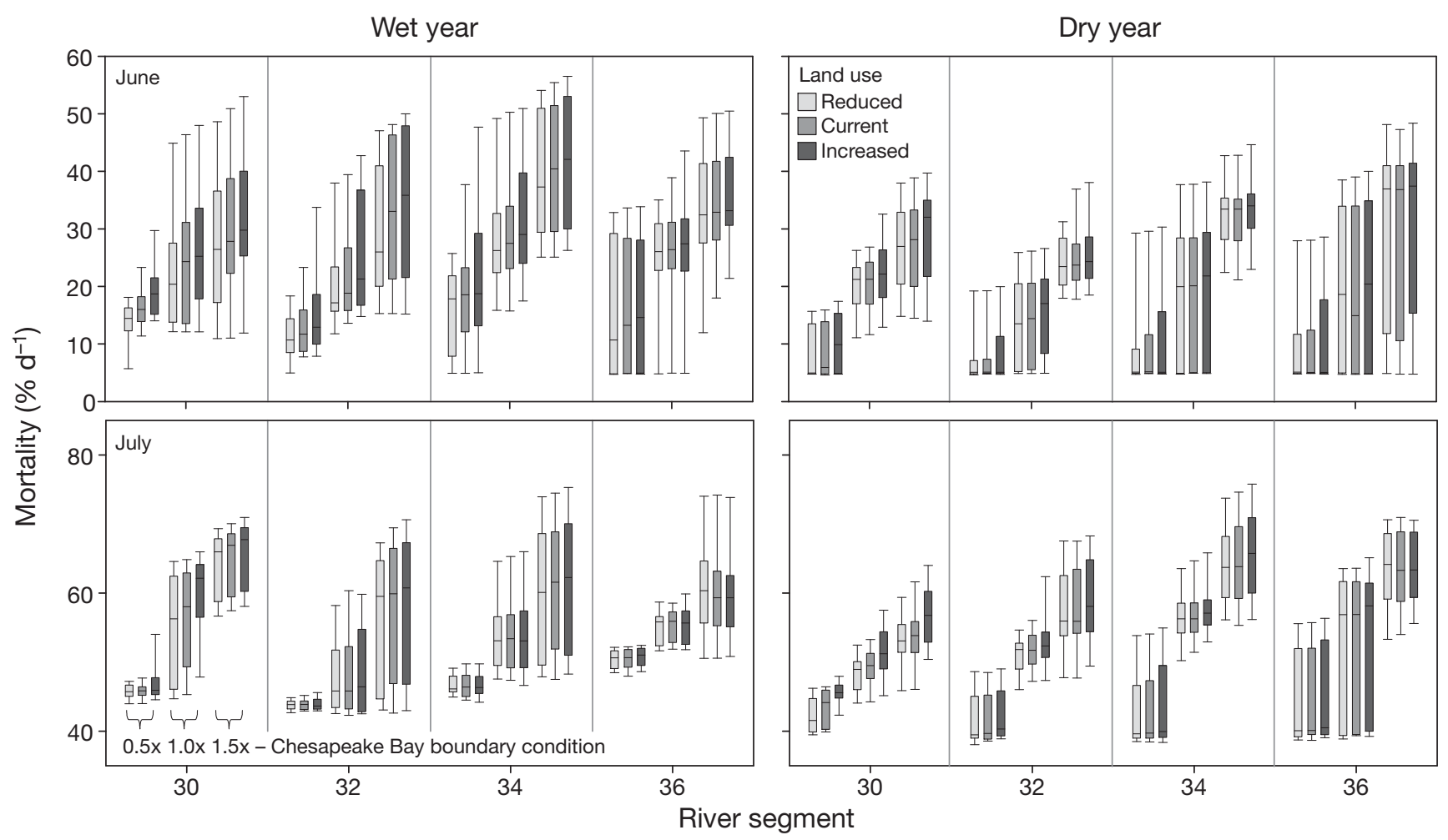

Fig. 8. Anchoa mitchilli. As in Fig. 7 except showing monthly $1 \mathrm{~d}$ egg mortality rates by year type (wet/dry), month and river segment. Note different $y$-axis scales for June and July

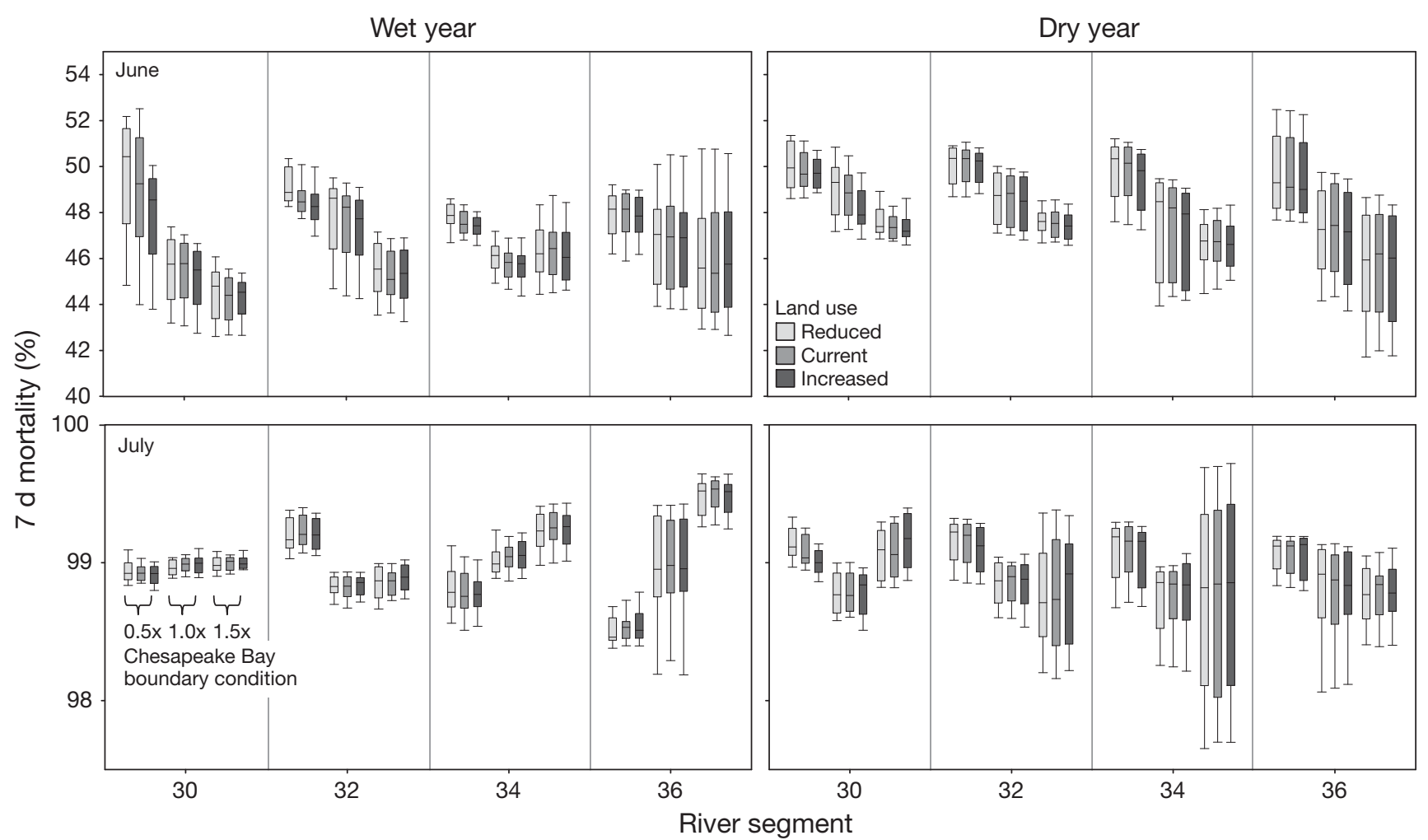

Fig. 9. Anchoa mitchilli. As in Fig. 7 except showing 7 d larval bay anchovy mortality rates by year type (wet/dry), month and river segment. Note different $y$-axis scales for June and July 




Fig. 10. Anchoa mitchilli and Mnemiopsis leidyi. Daily fraction of the larval bay anchovy and ctenophore populations by layer for June 14 to 18 in River Segment 34 for the wet year for the (A) $0.5 \times$ Chesapeake Bay boundary condition, (B) $1.0 \times$ baseline boundary condition, and (C) $1.5 \times$ boundary condition. Solid columns: anchovy distributions; cross hatched columns: ctenophore distributions

Larval mortality rates decreased in June under increasingly hypoxic conditions (increasing Chesapeake Bay boundary nutrient loads) because of changes in the vertical distributions of the larvae and their predators that resulted in different degrees of spatial overlap. Using the results for the $7 \mathrm{~d}$ period starting on June 14 in the wet year and current landuse scenarios, the $0.5 \times$ boundary condition resulted in bottom DO concentrations that retained larvae in the bottom layer with their ctenophore predators (Fig. 10A). About $20 \%$ of the larvae and 20 to $40 \%$ of the ctenophores were in the bottom layer. Under baseline boundary conditions, 40 to $50 \%$ of the ctenophores, but only $2 \%$ of larvae, were in the bottom layer because bottom DO was low enough to trigger avoidance by the larvae (Fig. 10B). Under the
$1.5 \times$ boundary condition, the bottom layer DO became low enough to force larvae to completely avoid the bottom layer, while 15 to $35 \%$ of the ctenophores remained in the bottom layer (Fig. 10C).

\section{DISCUSSION}

Chesapeake Bay water quality at the downstream boundary of the Patuxent River had a much larger effect on bay anchovy egg and larval mortality rates than nutrient loading rates from the Patuxent River watershed (Figs. 8 \& 9). This pattern was consistent with the predicted bottom layer DO concentrations from the water quality model that were used as inputs to the individual-based predation model simulations (Fig. 7). Lung \& Nice's (2007) analysis using the water quality model predicted that conditions at the Chesapeake Bay boundary would have a larger impact on DO concentrations in the lower estuary than changes in local Patuxent River watershed nutrient loadings. Lung \& Nice (2007) substantiated these results by showing that, during the 2 yr simulation period, the volume of water entering and exiting the mouth of the Patuxent during tidal exchange was nearly 10 -fold the volume of tributary inflow to the estuary. The finding is also consistent with other analyses (Hagy et al. 2000, 2004, Fisher et al. 2006, Boynton et al. 2008) that indicated that Chesapeake Bay affects lower Patuxent River water quality by being a source of nutrients and organic carbon during the summer and through intrusions of hypoxic water. Examination of the effects of increasing and decreasing nutrient loadings from the Patuxent River watershed showed that changes in nutrient loading caused a substantial difference in phytoplankton growth in both the upper and lower portions of the estuary and differences in DO concentrations in the upper estuary, but caused little or no difference in DO concentrations in the lower estuary.

Simulated bay anchovy egg mortality rates were strongly linked to the prevalence and intensity of hypoxia predicted by the water quality model, with higher DO concentrations (i.e. $0.5 \times$ boundary and reduced nutrient loading scenario) resulting in lower mortality rates (Fig. 8). On days when the bottom layer DO concentrations were $\leq 1 \mathrm{mg} \mathrm{l}^{-1}$, hypoxic conditions often extended into the pycnocline layer, and egg mortality rates could approach $50 \% \mathrm{~d}^{-1}$ or more (Fig. 5A versus C, Fig. 7 versus Fig. 8). Based on laboratory experiments, bay anchovy eggs are sensitive to hypoxia $\left(12 \mathrm{~h} \mathrm{LC}_{50}=2.8 \mathrm{mg} \mathrm{l}^{-1}\right.$; Chesney \& Houde 1989). Across river segments and year types (wet/ 
dry), bottom layer DO concentrations (Fig. 7) were sufficiently hypoxic on at least some of the days simulated for each of the 3 Chesapeake Bay boundary condition scenarios to account for a substantial component of egg mortality in the bottom layer (Fig. 5B).

Egg mortality rates due to hypoxia were also affected by water column structure. For example, DO concentrations in the bottom layer during the period from June 3 to 8 remained below $0.5 \mathrm{mg} \mathrm{l}^{-1}$, a concentration that causes $100 \%$ mortality of bay anchovy eggs. Predation was low under these conditions because there were no sea nettles present in June and ctenophores avoid DO concentrations $<0.5 \mathrm{mg} \mathrm{l}^{-1}$ (Fig. 4). The only factor remaining that could affect bay anchovy egg mortality rates was the fraction of the water column in the bottom layer. As the fraction of the water column in the bottom layer decreased from 0.26 on June 3 to 0.07 on June 8 (Fig. 5A), the percentage of eggs in the bottom layer declined from $23 \%$ on June 3 to $5 \%$ on June 8 (Fig. 5B). Changes in water column structure alone caused an $18 \%$ reduction in overall egg mortality rates. However, we note that, if DO concentrations in the pycnocline are also hypoxic, reductions in egg mortality in the bottom layer due to predators avoiding the bottom layer could be counteracted by increased DO-related mortality in the pycnocline.

Behavioral responses to bottom layer hypoxia altered encounter rates between larvae and their predators. This caused larval mortality rates during June, when ctenophores were the only predators, to have the opposite pattern of response (compared to egg mortality rates) to changes in the Chesapeake Bay boundary conditions. The $1.5 \times$ baseline boundary condition scenarios had the lowest median larval mortality rates during both the wet year and the dry year (Fig. 9). Mortality rates for the baseline boundary condition scenarios were similar or slightly higher to rates for the $1.5 \times$ baseline boundary condition scenarios, while the $0.5 \times$ baseline boundary condition scenarios always had the highest mortality rates. Mortality rates for the $1.5 \times$ and baseline boundary condition scenarios were lower than the $0.5 \times$ scenario because the former had lower DO concentrations in the bottom layer that caused larvae to move from the bottom layer to the pycnocline, while the DO was not low enough to cause avoidance by the ctenophores and they remained in the bottom layer (Fig. 10B,C). Thus, in the $1.5 \times$ and baseline boundary condition scenarios, the lower DO concentrations created a spatial refuge from predation for the larvae. In contrast, larvae and ctenophores in the $0.5 \times$ baseline boundary condition scenario tended to be more evenly distributed among the 3 layers of the water column (Fig. 10A), which resulted in a significant fraction of the larvae being exposed to predation.

Predicted bay anchovy egg and larval mortality rates were comparable to the mortality rates reported in the literature. June and July egg mortality rates ( 0.06 to $0.96 \mathrm{~d}^{-1}$ and 0.61 to $1.7 \mathrm{~d}^{-1}$, respectively) were within the range of the stage-specific mortality rates reported for eggs in July in Chesapeake Bay (0.02 to $4.69 \mathrm{~d}^{-1}$; Dorsey et al. 1996). However, the vast majority of egg mortality rates in our model scenarios were below Dorsey et al.'s (1996) average mortality rate of $1.6 \mathrm{~d}^{-1}$. Larval mortality rates for June ( 0.08 to $0.10 \mathrm{~d}^{-1}$ ) and for July ( 0.53 to $0.76 \mathrm{~d}^{-1}$ ) were within the range of rates $\left(0.08\right.$ to $\left.1.20 \mathrm{~d}^{-1}\right)$ reported for Chesapeake Bay by Cowan \& Houde (1990) and by MacGregor (1994). In contrast to Rilling \& Houde (1999), our simulated larval mortality rates were predicted to increase between June and July rather than decrease. The predicted June larval mortality rates were more typical of the rates reported for mesocosm studies (e.g. 0.08 to $0.23 \mathrm{~d}^{-1}$; Cowan \& Houde 1990), which excluded large predators (e.g. fish, ctenophores, and sea nettles), than for field studies (e.g. 0.23 to $1.20 \mathrm{~d}^{-1}$; MacGregor 1994), suggesting that fish and other non-gelatinous predators are important sources of mortality that were missed by our simulations during June. Larval mortality rates for July were towards the high end of the reported mortality rates (e.g. 0.30 to $0.45 \mathrm{~d}^{-1}$ in Leak \& Houde 1987; 0.32 to $0.89 \mathrm{~d}^{-1}$ in Castro \& Cowen $1991 ; 0.23$ to $1.20 \mathrm{~d}^{-1}$ in MacGregor 1994), suggesting that ctenophores and sea nettles account for most of the larval mortality in the field during July. With the exception of larval mortality rates for July, our results were consistent with the findings of Houde et al. (1994) that gelatinous predators were likely only responsible for $21.5 \%$ of egg mortality and $40 \%$ of larval mortality.

We did not focus on the growth rate responses of bay anchovy larvae to hypoxia, as the short duration of our simulations limited the potential for hypoxia to affect anchovy lengths and mortality rates through slower growth rates. Slower growth rates resulted in smaller anchovy, which reduced the number of encounters between anchovy and their predators (e.g. Eq. 1), but increased their vulnerability to capture by sea nettles and ctenophores (e.g. Table 1) and extended the length of time that they were vulnerable to capture. To examine the longer term effects of hypoxia on anchovy growth rates, we repeated a few simulations for $30 \mathrm{~d}$, and tallied the number of larvae surviving to certain lengths, regardless of how many 
days such growth required. We simulated Segment 34 under the dry year conditions during June for the contrasting conditions of reduced Patuxent watershed nutrient loadings with $0.5 \times$ boundary condition (highest DO simulation), current watershed nutrient loadings with baseline boundary condition (intermediate DO simulation), and increased nutrient loadings with $1.5 \times$ boundary condition (lowest DO simulation). Mean lengths of survivors at $30 \mathrm{~d}$ reflected the DO conditions, with mean length of survivors decreasing from the highest DO scenario to the lowest DO scenario $(8.46,7.65$, and $6.83 \mathrm{~mm}$, respectively). Interestingly, the percentage of survivors to different lengths $(5,6$, and $7 \mathrm{~mm}$, respectively) showed the opposite pattern of the $7 \mathrm{~d}$ mortality, with the numbers of survivors to a specific length increasing from the lowest DO simulation to the highest DO simulation. For example, the percentage of larvae reaching $7 \mathrm{~mm}$ was highest for the highest DO simulation $(9.6 \%)$ and lowest for the lowest DO simulation $(2.3 \%)$ despite the lowest DO simulation having lower overall mortality. This was because the slower growth rates in the lowest DO simulation resulted in more days being required to reach a set length, which resulted in higher cumulative mortality to a particular size (e.g. Houde 1987). Thus, our results using $7 \mathrm{~d}$ simulations, which showed that under low DO decreased larval mortality partially offset the increased egg mortality, could be an underestimate of the negative effects of hypoxia; longer model runs that use a fixed length as the endpoint and allowed the cumulative effects of slowed larval growth to accumulate would result in even higher mortality responses to low DO.

We highlight 5 main improvements to this analysis that would increase the realism of model predictions. (1) Expansion of the predator species mix to include fish (e.g. piscivorous fish larvae, weakfish, striped bass, bluefish) and other types of invertebrate predators would allow the model to account for more of the field-estimated mortality of anchovies during June.

(2) Model simulations could be expanded to include the effects of wet and dry years on sea nettle and ctenophore abundances. Jung \& Houde (2004) found that larval mortality rates in the mainstem of the Chesapeake Bay were lower in years with high salinity (dry years), potentially because of the effects of salinity on predator abundance and spatial distribution (Purcell \& Decker 2005). Year types (wet/dry) affect the spatial distribution of sea nettles (Decker et al. 2007), as well as the timing of peak sea nettle abundance (Breitburg \& Fulford 2006). The potential effect of year types on ctenophores is less clear, as they do not appear to be affected by temperature and salinity, but may be affected by food availability and sea nettle predation (Purcell \& Decker 2005).

(3) Larval growth rates in the individual-based model should be linked to chl a production from the water quality model in order to better represent the effects of changes in nutrient loading on larval fish growth. Unlike DO, chl a concentrations in the lower estuary were sensitive to changes in Patuxent River watershed nutrient loads (Lung \& Nice 2007). Differences in chl a concentrations among scenarios could affect the availability of micro- and meso-zooplankton prey for larval bay anchovy (Reaugh et al. 2007), thereby affecting larval growth rates (e.g. Saksena \& Houde 1972).

(4) The simulation of DO near the downstream boundary of the water quality model could be improved by allowing DO at the downstream boundary of the water quality model to vary under the reduced and increased Chesapeake Bay boundary condition scenarios and in response to changes in nutrient loads from the Patuxent River. Our Chesapeake Bay boundary condition scenarios included changes in nutrient concentrations and carbonaceous biochemical oxygen demand at the downstream boundary conditions, but did not include changes to DO. A bay-wide water quality model (CE-QUAL-ICM model developed for Chesapeake Bay) predicted changes in DO of about $1 \mathrm{mg} \mathrm{l}^{-1}$ at the mouth of the Patuxent River when Chesapeake Bay nutrient loads were varied by $\pm 50 \%$ (Adamack 2007). If these changes propagate upstream into the Patuxent River, then changing the DO due to the Chesapeake Bay boundary conditions could affect egg and larval survival on days when DO was close to the mortality threshold. Additionally, changes in nutrient loadings to the Patuxent River had no subsequent effect on nutrient loads at the downstream boundary nor on DO concentrations.

(5) We could modify the model to allow simulations to be continuous from eggs through the first week of life of larvae or longer. The counter-acting dependence of egg and larval mortality on nutrient loadings makes it difficult to predict the net effect from separate egg and larval simulations. Simulations that go from egg through larvae would integrate these counter-acting effects of water quality, thereby giving a clearer overall view of water quality effects on early life stage survival of bay anchovy.

Our analysis focused on only 1 aspect of the effects of water quality (i.e. anchovy egg and larval mortality), and should not be interpreted as suggesting that reduced nutrient loadings from the Patuxent water- 
shed would have no beneficial effects. This would be an improper extrapolation of our modeling results. Land-use scenarios did cause large differences in productivity and DO in upstream portions (Segments 15 to 25 in Fig. 2) of the Patuxent River (Lung \& Nice 2007), where the effects of watershed nutrient loadings are more dominant. In the lower portion of the estuary, which was the focus of the present study, there were episodes (a few days) during which changes in land use caused differences in egg mortality rates (e.g. June 2 to 9; Fig. 5C), but these were relatively rare. The relatively limited effects of reduced nutrient loadings from the watershed on lower estuary water quality are likely the result of interactions with nutrient-rich water from Chesapeake Bay entering the lower estuary (Nice 2006, Testa et al. 2008). Nice (2006) noted that his simulations showed that 'the large impact of downstream boundary conditions on DO concentrations in the lower estuary coupled with the lack of sensitivity to nutrient loadings from upstream tributaries implies that water quality at Broomes Island and the lower portions of the estuary will not improve without bay-wide reductions in nutrient loadings' (p. 65). As the Patuxent River is a net contributor of organic nitrogen to Chesapeake Bay (Boynton et al. 1995), the bay-wide reductions in nutrient loadings that are needed to improve water quality in the lower estuary could be met, in part, by reduced nutrient loadings from the Patuxent watershed. The level of reduction in loadings from the local watershed that is needed to evoke a meaningful response in egg and larval survival in the lower Patuxent River by affecting the Chesapeake Bay boundary condition is likely substantial. Land-use planning and nutrient loading reduction strategies should consider both local (specific watershed) and regional (bay-wide) conditions, and the specifics of the life cycle, tolerances, and behavior of the species of interest and their prey and predators.

Acknowledgements. The authors thank D. E. Weller and T. E. Jordan for providing the use of nutrient and flow loading results from their watershed sampling and modeling efforts, and T. R. Fisher for providing his pycnocline detection algorithm. We also thank J. H. Cowan Jr. for his comments on early versions of the manuscript, D. E. Weller for the use of a graphic and S. E. Kolesar for the use of her field data. A.T.A. was supported by an assistantship from the Department of Oceanography and Coastal Sciences at Louisiana State University and was partially support by NOAA-GLERL while completing the manuscript. Portions of K.A.R.'s efforts on this research were supported by the NOAA Coastal Ocean Program Gulf of Mexico GOMEX Grant No. NA09NOS4780179 to P. Thomas and NOS National Center for Coastal Ocean Science Coastal Hypoxia
Research Program (CHRP) Grant No. NA10NOS4780157 to K.A.R. This is NGOMEX and CHRP Publication 149. Contributions by D.L.B., A.J.N., and W.S.L. were supported by NOAA CSCOR Grants NA03NOS4780008 and NA96OP0032.

\section{LITERATURE CITED}

Adamack AT (2007) Predicting water quality effects on bay anchovy (Anchoa mitchilli) growth and production in Chesapeake Bay: linking water quality and individualbased fish models. PhD dissertation, Louisiana State University, Baton Rouge, LA

> Bailey KM, Batty RS (1983) A laboratory study of predation by Aurelia aurita on larval herring (Clupea harengus): experimental observations compared with model predictions. Mar Biol 72:295-301

Baird D, Ulanowicz RE (1989) The seasonal dynamics of the Chesapeake Bay ecosystem. Ecol Monogr 59:329-364

Bockstael NE, Irwin EG (2003) Public policy and the changing landscape. Estuaries 26:210-225

Boesch DF, Brinsfield RB, Magnien RE (2001) Chesapeake Bay eutrophication: scientific understanding, ecosystem restoration, and challenges for agriculture. J Environ Qual 30:303-320

- Boynton WR, Garber JH, Summers R, Kemp WM (1995) Inputs, transformations, and transport of nitrogen and phosphorus in Chesapeake Bay and selected tributaries. Estuaries 18:285-314

Boynton WR, Hagy JD, Cornwell JC, Kemp WM and others (2008) Nutrient budgets and management actions in the Patuxent River Estuary, Maryland. Estuaries Coasts 31: 623-651

Breitburg DL (1992) Episodic hypoxia in Chesapeake Bay: interacting effects of recruitment, behavior, and physical disturbance. Ecol Monogr 62:525-546

> Breitburg DL (1994) Behavioral response of fish larvae to low dissolved oxygen concentrations in a stratified water column. Mar Biol 120:615-625

Breitburg DL, Fulford RS (2006) Oyster-sea nettle interdependence and altered control within the Chesapeake Bay ecosystem. Estuaries Coasts 29:776-784

Breitburg DL, Rose KA, Cowan JH Jr (1999) Linking water quality to larval survival: predation mortality of fish larvae in an oxygen-stratified water column. Mar Ecol Prog Ser 178:39-54

> Breitburg DL, Adamack A, Rose KA, Kolesar SE and others (2003) The pattern and influence of low dissolved oxygen in the Patuxent River, a seasonally hypoxic estuary. Estuaries 26:280-297

Breitburg DL, Craig JK, Fulford RS, Rose KA and others (2009) Nutrient enrichment and fisheries exploitation: interactive effects on estuarine living resources and their management. Hydrobiologia 629:31-47

> Castro LR, Cowen RK (1991) Environmental factors affecting the early life history of bay anchovy Anchoa mitchilli in Great South Bay, New York. Mar Ecol Prog Ser 76: 235-247

Chesney EJ, Houde ED (1989) Laboratory studies on the effect of hypoxic waters on the survival of eggs and yolksac larvae of the bay anchovy, Anchoa mitchilli. In: Houde ED, Chesney EJ, Newberger TA, Vasquez AV and others (eds) Population biology of bay anchovy in mid-Chesapeake Bay. Final report to Maryland Sea 
Grant Ref. No. (UM-CEES) CBL 89-141. Center for Environmental and Estuarine Studies, Chesapeak Biological Laboratory, Solomons, MD, p 184-191

Cole TM, Wells SA (2000) CE-QUAL-W2: a two-dimensional, laterally averaged, hydrodynamic and water quality model, Version 3.0. US Army Corps of Engineers, Washington, DC

> Correll DL, Jordan TE, Weller DE (1999) Effects of interannual variation of precipitation on stream discharge from Rhode River subwatersheds. J Am Water Resour Assoc 35:73-82

> Cowan JH Jr, Houde ED (1990) Growth and survival of bay anchovy (Anchoa mitchilli) larvae in mesocosm enclosures. Mar Ecol Prog Ser 68:47-57

> Cowan JH Jr, Houde ED (1992) Size-dependent predation on marine fish larvae by ctenophores, scyphomedusae and planktivorous fish. Fish Oceanogr 1:113-126

> Cronin TM, Vann CD (2003) The sedimentary record of climatic and anthropogenic influence on the Patuxent Estuary and Chesapeake Bay ecosystems. Estuaries 26: 196-209

> D'Elia CF, Boynton WR, Sanders JG (2003) A watershed perspective on nutrient enrichment, science and policy in the Patuxent River, Maryland: 1960-2000. Estuaries 26: 171-185

de Jong F (2006) Marine eutrophication in perspective: on the relevance of ecology for environmental policy. Springer, Berlin

Decker MB, Brown CW, Hood RR, Purcell JE and others (2007) Predicting the distribution of the scyphomedusa Chrysaora quinquecirrha in Chesapeake Bay. Mar Ecol Prog Ser 329:99-113

> Diaz RJ, Rosenberg R (2008) Spreading dead zones and consequences for marine ecoystems. Science 321:926-929

Dorsey SE, Houde ED, Gamble JC (1996) Cohort abundances and daily variability in mortality of eggs and yolk-sac larvae of bay anchovy, Anchoa mitchilli in Chesapeake Bay. Fish Bull 94:257-267

EPA (Environmental Protection Agency) (2003) Technical support document for identification of Chesapeake Bay designated uses and attainability. US EPA Region III, Chesapeake Bay Program Office, Annapolis, MD

> Fisher TR, Hagy JD III, Boynton WR, Williams MR (2006) Cultural eutrophication in the Choptank and Patuxent estuaries of Chesapeake Bay. Limnol Oceanogr 51:435-447

Fofonoff NP, Millard RC Jr (1983) Algorithms for computation of fundamental properties of seawater. UNESCO Tech Pap Mar Sci 44

Gerritsen J, Strickler JR (1977) Encounter probabilities and community structure in zooplankton: a mathematical model. J Fish Res Board Can 34:73-82

Hagy JD, Boynton WR, Sanford LP (2000) Estimation of net physical transport and hydraulic residence times for a coastal plain estuary using box models. Estuaries 23: 328-340

> Hagy JD, Boynton WR, Keefe CW, Wood KV (2004) Hypoxia in Chesapeake Bay, 1950-2001: long-term change in relation to nutrient loading and river flow. Estuaries 27: 634-658

Homer C, Dewitz J, Fry J, Coan M and others (2007) Completion of the 2001 National Land Cover Database for the Conterminous United States. Photogramm Eng Remote Sens 73:337-341

Houde ED (1987) Fish early life dynamics and recruitment variability. Am Fish Soc Symp 2:17-29
Houde ED, Gamble JC, Dorsey SE, Cowan JH Jr (1994) Drifting mesocosms: the influence of gelatinous zooplankton on mortality of bay anchovy, Anchoa mitchilli, eggs and yolk-sac larvae. ICES J Mar Sci 51:383-394

> Jordan TE, Weller DE, Correll DL (2003) Sources of nutrient inputs to the Patuxent River estuary. Estuaries 26: 226-243

Jung S, Houde ED (2004) Production of bay anchovy Anchoa mitchilli in Chesapeake Bay: application of size-based theory. Mar Ecol Prog Ser 281:217-232

Keister JE, Houde ED, Breitburg DL (2000) Effects of bottom-layer hypoxia on abundances and depth distributions of organisms in Patuxent River, Chesapeake Bay. Mar Ecol Prog Ser 205:43-59

Kemp WM, Boynton WR, Adolf JE, Boesch DF and others (2005) Eutrophication of Chesapeake Bay: historical trends and ecological interactions. Mar Ecol Prog Ser 303:1-29

Kolesar SE (2006) The effects of low dissolved oxygen on predation interactions between Mnemiopsis leidyi ctenophores and larval fish in the Chesapeake Bay ecosystem. PhD dissertation, University of Maryland, College Park, $\mathrm{MD}$

> Leak JC, Houde ED (1987) Cohort growth and survival of bay anchovy Anchoa mitchilli larvae in Biscayne Bay, Florida. Mar Ecol Prog Ser 37:109-122

$>$ Lung WS, Bai S (2003) A water quality model for the Patuxent estuary: current conditions and predictions under changing land-use scenarios. Estuaries 26:267-279

Lung WS, Nice AJ (2007) Eutrophication model for the Patuxent Estuary: advances in predictive capabilities. J Environ Eng 133:917-930

MacGregor JM (1994) Offshore-onshore pattern and variability in abundance and distribution of bay anchovy, Anchoa mitchilli, eggs and larvae in Chesapeake Bay. MSc thesis, University of Maryland, College Park, MD

Mississippi River/Gulf of Mexico Watershed Nutrient Task Force (2008) Gulf Hypoxia Action Plan 2008 for reducing, mitigating, and controlling hypoxia in the northern Gulf of Mexico and improving water quality in the Mississippi River Basin. Washington, DC

Nice AJ (2006) Developing a fate and transport model for arsenic in estuaries. PhD dissertation, University of Virginia, Charlottesville, VA

NOAA (National Oceanic and Atmospheric Administration) (2003) Water level data collected at the Center for Operational Oceanographic Products and Services (CO-OPS) Station 8577330, Solomons Island, MD, from November 1937 through present. Available at: www.tidesand currents.noaa.gov (accessed on 6 January 2012)

Pihl L, Baden SP, Diaz RJ (1991) Effects of periodic hypoxia on distribution of demersal fish and crustaceans. Mar Biol 108:349-36

Powledge F (2005) Chesapeake Bay restoration: a model of what? Bioscience 55:1032-1038

Purcell JE, Decker MB (2005) Effects of climate on relative predation by scyphomedusae and ctenophores on copepods in Chesapeake Bay during 1987-2000. Limnol Oceanogr 50:376-387

Reaugh ML, Roman MR, Stoecker DK (2007) Changes in plankton community structure and function in response to variable freshwater flow in two tributaries of the Chesapeake Bay. Estuar Coast 30:403-417

Rilling GC, Houde ED (1999) Regional and temporal variability in growth and mortality of bay anchovy, Anchoa 
mitchilli, larvae in Chesapeake Bay. Fish Bull 97: 555-569

Rose KA, Cowan JH, Clarke ME, Houde ED, Wang SB (1999) An individual-based model of bay anchovy population dynamics in the mesohaline region of Chesapeake Bay. Mar Ecol Prog Ser 185:113-132

Rose KA, Adamack AT, Murphy CA, Sable SE and others (2009) Does hypoxia have population-level effects on coastal fish? Musings from the virtual world. J Exp Mar Biol Ecol 381:S188-S203

Saksena VP, Houde ED (1972) Effect of food level on the growth and survival of laboratory-reared larvae of bay anchovy (Anchoa mitchilli Valenciennes) and scaled sardine (Harengula pensacolae Goode \& Bean). J Exp Mar Biol Ecol 8:249-258

Testa JM, Kemp WM, Boynton WR, Hagy JD (2008) Long term changes in water quality and productivity in the Patuxent River estuary: 1985 to 2003. Estuaries Coasts 31:1021-1037

Weller DE, Jordan TE, Correll DL, Liu ZJ (2003) Effects of land-use change on nutrient discharges from the Patuxent River watershed. Estuaries 26:244-266

Zastrow CE, Houde ED, Moring LG (1991) Spawning, fecundity, hatch-date frequency and young-of-the-year growth of bay anchovy Anchoa mitchilli in mid-Chesapeake Bay. Mar Ecol Prog Ser 73:161-171 
Appendix. Additional information on the pycnocline detection algorithm used to determine water column layers for use in the individual-based predation model

The 3-layer water column structure used for the individual-based predation model was determined each day of the modeled time period by applying a pycnocline detection algorithm to the output of the water quality model. The detection algorithm was developed and provided to the authors by T. R. Fisher of the Horn Point Laboratory, Center for Environmental Science, University of Maryland, 2020 Horn Point Rd, Cambridge, Maryland 21613, USA. Because the algorithm has not been published in its entirety, we describe it in detail here and illustrate how it works with some results from our linked model analysis.

To find the location of the pycnocline, we first calculated the seawater density anomaly $\left(\sigma_{t}\right)$ for each vertical cell in a river segment on a given day. $\sigma_{t}$ was determined by applying an algorithm (Fofonoff \& Millard 1983) for determining $\sigma_{t}$ from temperature and salinity. We then developed depth profiles of $\sigma_{t}$ (Fig. A1), setting the depth of each $\sigma_{t}$ value to the depth of the top of its cell ( $1 \mathrm{~m}$ depth increments). Next, we calculated the rate at which $\sigma_{t}$ changed between depth intervals (i.e. the slope of the line between sequential $\sigma_{t}$ values), starting at the water column surface and ending at the bottom. The pycnocline detection algorithm was then applied to these rates of change in $\sigma_{t}$ using the following rules (EPA 2003):

(1) Examine the slopes of $\sigma_{\mathrm{t}}$ starting at the water surface, and the first cell that has a slope $>0.1 \mathrm{~kg} \mathrm{~m}^{-4}$ (the density gradient at which water exchange is inhibited or prevented) is designated as the upper pycnocline depth, provided that:

(a) that cell is not the surface cell, and

(b) the next slope below it is positive.

(2) Examine the slopes in $\sigma_{t}$ from the bottom, and the first cell that has a slope $>0.2 \mathrm{~kg} \mathrm{~m}^{-4}$ (the density gradient at which upward vertical exchange is inhibited) is designated as the lower pycnocline depth, provided that:

(a) an upper pycnocline depth exists,

(b) there is a bottom mixed layer, defined as the first or second slope from the bottom being $<0.2 \mathrm{~kg} \mathrm{~m}^{-4}$, and

(c) the next slope above it is positive.

We modified these rules slightly in 2 ways. First, if the algorithm did not find a lower pycnocline depth, then we used the lower pycnocline depth from a similar scenario (i.e. same Chesapeake Bay boundary conditions, but different Patuxent River watershed land-use scenario) for the same river segment on the same day. If a lower pycnocline depth was not detected in any of the similar scenarios, then we set the lower pycnocline depth to the midpoint between the upper pycnocline depth and the bottom. The second modification was that if the algorithm did not find an upper pycnocline depth, we divided the water column into thirds. The individual-based predation model required 3 layers, but if DO was similar among layers, then the individual-based model essentially was simulating a well-mixed water column. Similar DO values in the 3 layers would result in small and uniform direct effects on mortality, growth, and capture success among the layers, and vertical distribution of individuals in proportion to the volumes of the 3 layers.

The pycnocline detection algorithm consistently generated reasonable upper and lower pycnocline depths. We illustrate the results of the algorithm using vertical profiles of $\sigma_{t}$ for $12 \mathrm{~d}$ in River Segment 34 from the wet year.
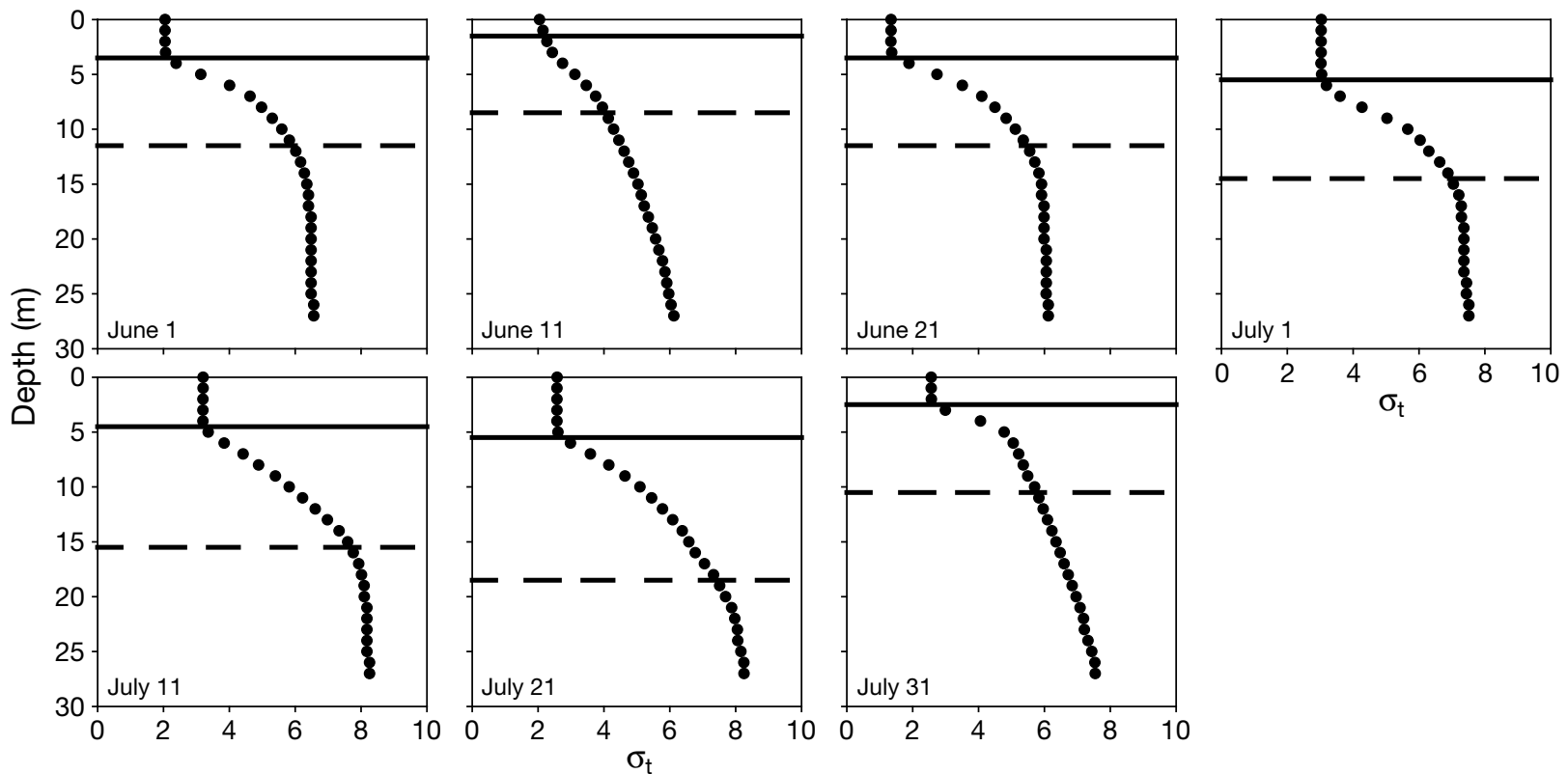

Fig. A1. Vertical profiles of the slopes of seawater density ( $\sigma_{t ;}$ solid dots) and the upper (solid line) and lower (dashed line) pycnocline depths determined by the pycnocline detection algorithm at 10 d intervals from June 1 through July 31 for River Segment 34 in the wet year 